\title{
Mirrors on the Land: Histories of New Zealand's Lakes
}

\author{
JONATHAN WEST
}

This article is a revised version of the J. D. Stout Lecture 2019. ${ }^{1}$

Freshwater quality is New Zealanders' number one environmental concern, even in the face of mass species extinction and of climate change. ${ }^{2}$

The politics of freshwater quality here are fraught, subject to claim and counterclaim, division and controversy over who is to blame. City is pitted against country, conservation flails against development, individual property rights are asserted against the common wealth in our waters. Inflamed debates raise questions that cut to our core, and set our sense of the past against our vision of the future: Who are we, if not a nation of farmers? Who will we become, if we cannot again live in a land of clean waters?

The pitch of public rhetoric is such that it is hard to judge: just how bad are our freshwater quality problems? How have we reached this point? And what does this mean for what can be done?

Water quality problems in lakes are caused by what we do on the land around them. They are overwhelmingly a result of pollution by nutrients, sediment and pathogens from the land. In lakes, the primary problem is with the nutrients phosphorus and nitrogen. ${ }^{3}$ Phosphorus is borne into lakes by water, largely in suspension with sediment. Nitrogen travels even more insidiously, in solution. This is almost all diffuse pollution: point source (pipe) nutrient pollution is now insignificant in New Zealand, accounting for just 3 percent of the total nitrogen and under 2 percent of phosphorus fluxes from the land. ${ }^{4}$

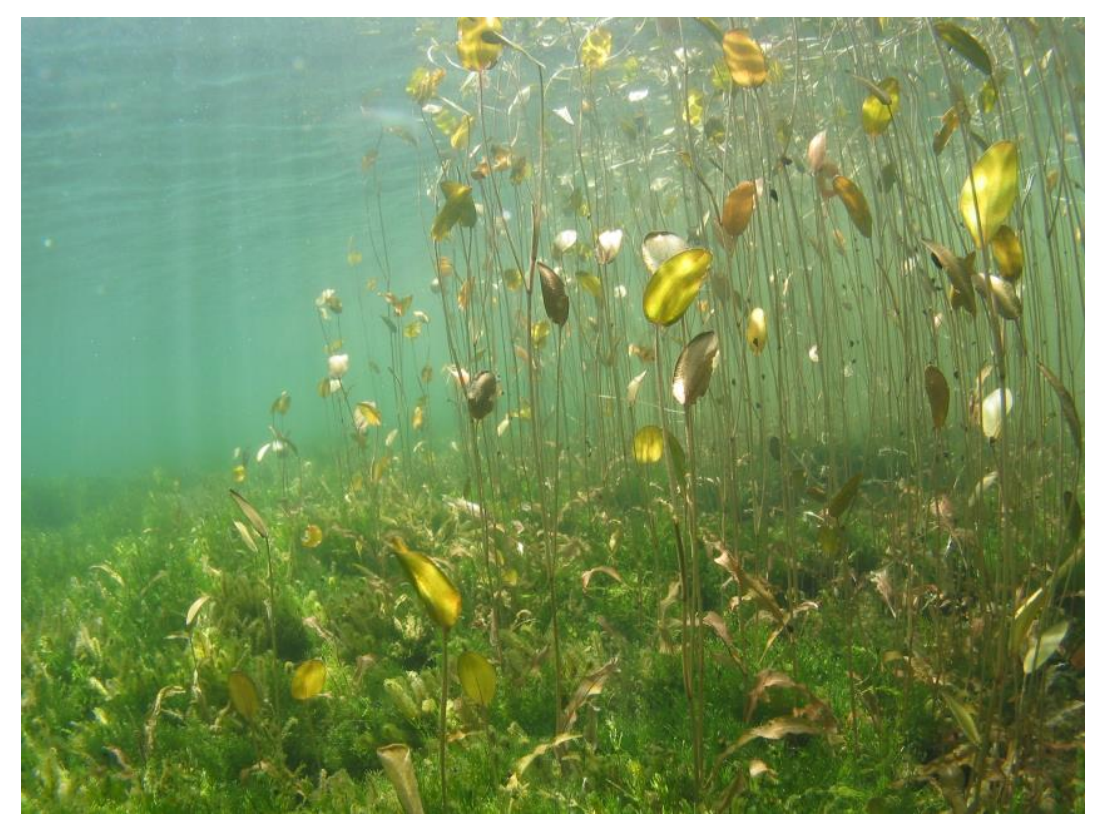

Figure 1. Pondweed Potamogeton cheesemanii, growing amongst meadow of native charophytes in Lake Ototoa, at the south head of Kaipara Harbour. (Photograph: Rohan Wells, NIWA.) 


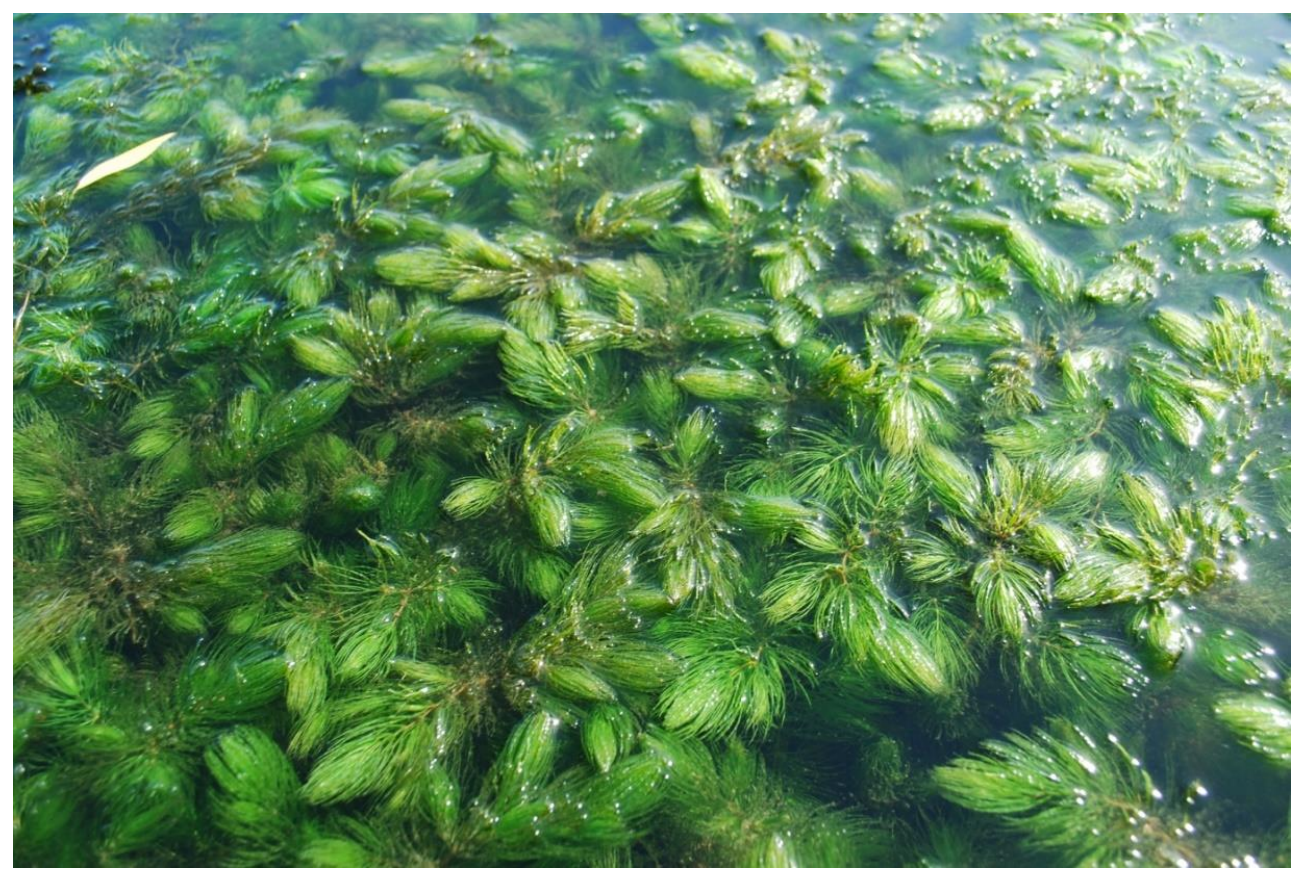

Figure 2. Invasive hornwort Ceratophyllum demersum, swamping Lake Kaituna. (Photograph: Rohan Wells, NIWA.)

Many New Zealand lakes suffer from invasive species. The spread of smothering aquatic plants such as hornwort (Ceratophyllum demersum), the arrival of predatory catfish to the Rotorua lakes, and problems with slimes of "lake snow" or "snot" (from blooms of the algal diatom Lindavia intermedia) in Lake Wanaka are just a few high-profile examples. ${ }^{5}$ Meanwhile, most New Zealand native fish species are threatened with extinction. These challenges of biodiversity increasingly preoccupy efforts to restore our lakes. ${ }^{6}$

However, our primary problem in lakes - as with freshwater and coastal marine ecosystems worldwide - has long been something scientists call eutrophication. ${ }^{7}$ Eutrophication means to make nutrient rich; to make fertile. ${ }^{8}$ It refers to the enrichment of water with nutrients, above all nitrogen and phosphorus. We do not like fertility in freshwater. It fuels plant growth and creates algal blooms, some toxic to human health, all problematic for ecosystem health. ${ }^{9}$

The solutions to our problems with lakes lie on the land. Our problems with lakes are a legacy of the whole history of New Zealand's settlement. Lakes accumulate. Layers of algae, plants and sediment are laid down over time on their beds, tracing a record of change in their catchments. Lake beds, then, are nature's archives, "geological whakapapa." 10 Lakes are mirrors on the land. Moreover, lakes are the land's focal points. That is why lakes are the perfect lens through which to understand, not only changes in the land, but changes in ourselves.

If our problems with lakes reflect our whole history, then, equally, to resolve our problems with lakes will likely take decades, if not in some cases generations: restoring our lakes is, as the Parliamentary Commissioner for the Environment has put it, "the ultimate endurance challenge."11 
A precondition for success in this challenge is good data. The closer I look, the worse I think our data is. New Zealand has some 50,000 lakes, of which 3800 are bigger than a hectare. ${ }^{12}$ We monitor water quality in only 160 - less than 5 percent — of those larger lakes. ${ }^{13}$ Even that monitoring is inconsistent, as regional councils use different protocols, so that data from only some lakes - usually well under 100 - is fit for comparative purposes. ${ }^{14}$ Lake eutrophication in New Zealand is typically described using the Trophic Level Index (TLI). This combines measurements of nitrogen and phosphorus with chlorophyll (essentially a proxy for algal biomass). Measurements of water clarity are regularly included. ${ }^{15}$ Lakes are then placed on a scale from oligotrophic, clear and blue, through eutrophic-nutrient enriched, green and murky - to hypertrophic, so severely degraded they may no longer be suitable for many valued species - kakahi and kōura (freshwater mussels and crayfish), or trout, for example. Or people. Eutrophic lakes bloom with algae, and some blooms - the blue-green (cyanobacterial) onescan be highly toxic, have killed stock and dogs, and could sicken and even conceivably kill people, were any foolish enough to drink the water. ${ }^{16}$

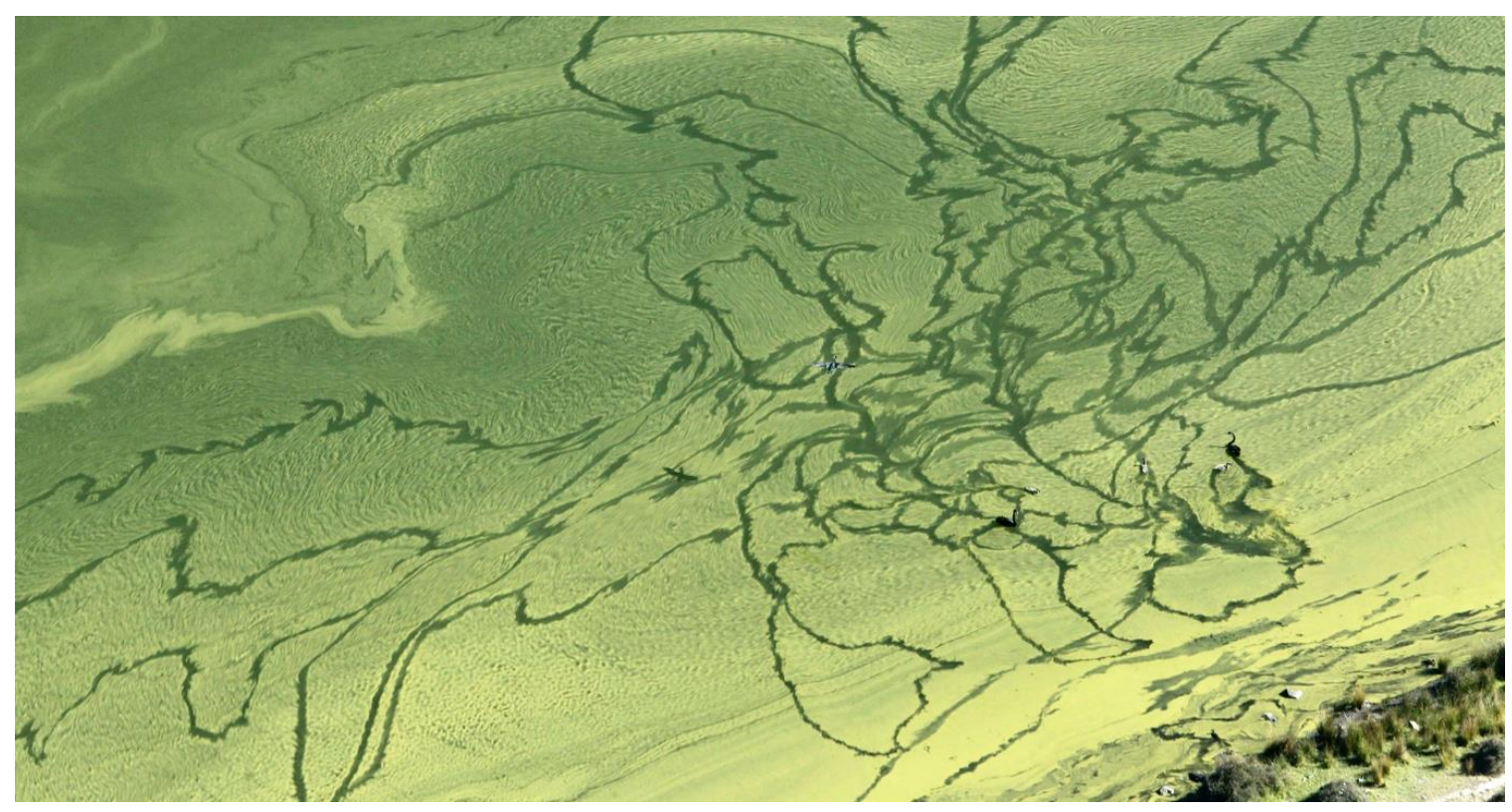

Figure 3. Black swans cut trails through an algal bloom on Lake Forsyth.

(Photograph: Richard Cosgrove.)

The causes of eutrophication here are well-known. While urban runoff and stormwater is responsible for some of our most polluted waterways, overall, agriculture is the primary driver. ${ }^{17}$ And this is not at all new information. Minister for the Environment David Parker refers to Parliamentary Commissioner for the Environment Morgan Williams' 2004 report Growing for Good as first letting us all know that the intensification of farming poses a serious problem for freshwater. ${ }^{18}$ But scientists—and government—-knew long before that.

Concern about eutrophication in New Zealand dates to just before 1970, when scientists here panicked at the prospect that we were poised to follow Europe and North America, where even very large lakes were facing severe problems with freshwater quality. Leading limnologist (lakes scientist) Eddie White recalled that the fear was "the Waikato River might become like the Rhine or the Mississippi, that Lake Rotorua might become another Lake Erie, or Taupo a Lake Constance." 19 This stimulated the establishment of the Department of Science and 
Industrial Research's (DSIR) freshwater section in 1969. As its leader, Eddie White transplanted this group to Taupō from 1973, to treat New Zealand's biggest lake, with a yet largely undeveloped catchment, as a test case, seeking to make a long-term, comprehensive study of the lake's ecosystem. ${ }^{20}$

Over the next decade, Eddie White and his team established a clear correlation between intensity of agricultural land use and the distribution of New Zealand's polluted lakes: all the enriched lakes were in catchments with higher stocking rates and more fertiliser use. ${ }^{21}$ In 1977 White prophetically warned that the intensity of agricultural land use "in much of New Zealand is sufficient to make most lakes prone to eutrophication. Only upland lakes of the South Island are substantially free of the problem. There seems to be little prospect of improving water quality ... without major reductions in the intensity of land use." 22

However, by 1982 Eddie White was concluding that the initial panic had been "an overreaction." "Eutrophication is here. It will worsen insidiously, and require control in places" but, he stated, "rapid and widespread degradation will not occur." ${ }^{23}$ This was mainly because, he had realised, nitrogen pollution was much lower in New Zealand than in the Northern Hemisphere. ${ }^{24}$ In Europe and America, eutrophication is treated purely as a function of phosphorus pollution-but that is because they have lost control of nitrogen. ${ }^{25}$ Decades of fossil fuel use mean the north's atmosphere is so saturated in nitrogen oxides that there, rain is fertiliser. By contrast, New Zealand has very little atmospheric nitrogen pollution. Lake Taupō was pristine - the purest New Zealand lake he'd studied. But place Taupō in the northern hemisphere, Eddie pointed out, and it had sufficient phosphorus to be mesotrophic - heading towards green and murky. ${ }^{26}$

So if nitrogen levels ever did increase in New Zealand, Eddie White warned in 1982, then "eutrophication may yet become a major management problem." ${ }^{27} \mathrm{He}$ did so with the benefit of the recently-released landmark report, The Effects of Land use on Water Quality, the culmination of ten years of work by New Zealand scientists on eutrophication, jointly produced by the National Water and Soil Conservation Organisation and the Officials Committee on Eutrophication. ${ }^{28}$ The former body was the umbrella group ultimately responsible for managing freshwater in New Zealand. The latter was a body of senior government officials originally convened in 1965 as the Interdepartmental Committee on Lakeweed, but which soon gained a broader remit to advise the Minister of Science on the DSIR's newly expanded research into the principles, causes and effects of eutrophication, to coordinate and improve research nationwide into eutrophication, and to "pay particular attention to the effects of different land management practices." 29 Throughout the 1970s this Committee led a sustained government effort to tackle the problem of eutrophication. The Effects of Land use on Water Quality was its last publication. In it, White's colleagues Rob McColl and Helen Hughes highlighted how hard it was to control nitrogen leaching from diffuse sources such as cattle urine patches, and the pressing need for research to address the looming problem. ${ }^{30}$

As the DSIR scientists knew all too well, Rob Muldoon's National Government was in the process of opening the Kapuni ammonia urea plant to manufacture nitrogen fertiliser. When the Officials Committee on Eutrophication discussed its implications, Rob McColl presciently feared that "use of bag nitrogen would increase the $\mathrm{N}$ content of pastures, stimulate clover fixation, increase food available, increase stock numbers, increase dung and urine and therefore increase not only the amount of nitrate leaching but also cause extra surface run off because of increased treading." 31 The Committee wrote to the Minister of Science and Technology, to 
disagree with advice from the National Water And Soil Conservation Organisation (NWASCO) that the plant's production posed no potential threat, and instead to warn of the need to minimise nitrogen leaching from pastoral grazing, identify problem parts of the country, and monitor nitrate levels. ${ }^{32}$ However, this was the Committee's final act before being disbanded, perceived as a redundant rival to the all-encompassing NWASCO. Eddie White, for one, felt this a "near-disaster situation for the battle to counter eutrophication." 33

And this brings me to the implications of the more or less "continuous thrust" to intensify New Zealand farming ever since the removal of agricultural subsidies in the mid-1980s. ${ }^{34}$ A key driver has been cheap synthetic nitrogen fertiliser, brought down from the sky using fossil fuels: brot aus luft, "bread from air" as Fritz Haber the inventor of this process put it; manna from heaven. ${ }^{35}$ In using it, we belatedly joined the rest of the world-for this is the defining feature of agricultural modernity, the consequence of breaching a barrier as profound as the nuclear one. Synthetic nitrogen now feeds half the world's population. ${ }^{36}$ And we are now world leaders in the intensity of our fertiliser use. ${ }^{37}$

Increased nitrogen fertiliser use (alongside irrigation and imported feed) has accompanied the shift from sheep and beef farming to dairy. ${ }^{38}$ And dairy stock density is the crux of our nitrogen problem. It is the sheer number and size of dairy cows - and hence the intensity of their pee and poo - that has propelled our skyrocketing rates of nitrogen leaching. ${ }^{39}$

How bad, then, have our lakes become? Somewhat mysteriously, studies done for the Ministry for the Environment's national reporting no longer correlate catchment use and lake water quality. The last time they did was in 2010. Of 50 monitored lakes with pastoral catchments, 43 were more or less polluted. ${ }^{40}$ The seven that weren't were Canterbury high country lakeswhose catchments have carried only a thin skein of sheep. And even they seem to have been sliding since, so now of those seven only Lake Benmore can confidently be said to have good water quality. ${ }^{41}$ Eddie White's prophecy has come to pass.

To conclude my assessment of our current problem: We have either farmed intensively, or we have had good water quality. But not both, not in the same catchment. We have instead shifted the whole bandwidth: once, our lakes were mostly oligotrophic, clear and blue; perhaps only one in twenty lakes was eutrophic. But now about half of our monitored lakes are eutrophic, and perhaps a third of all lakes may be. ${ }^{42}$

Perhaps in the future things will be different; perhaps we can turn things around. Alison Dewes has shown, for example, that dairy farmers can cut nitrogen losses 30 percent or more, and in only five years, without necessarily affecting profits. ${ }^{43}$ Perhaps we do not yet know if intensive farming and good water quality can coexist. Do we dare hope so?

One reason for doubt is that climate change is already exacerbating eutrophication. ${ }^{44}$ Another is that lakes suffering eutrophication can cross ecological tipping points, and "flip" from being full of weeds to choked with algae - sometimes permanently, sometimes oscillating back and forth-but in either case we have had little success restabilising the situation. ${ }^{45}$ The Wahine storm wiped out the weed beds of Lake Ellesmere (Te Waihora) in 1968; they have never returned. ${ }^{46}$

A final and related problem is captured in what lake scientists call hysteresis, a lovely word which refers to the fact that the pathways to initial degradation and to recovery are different. Simply retracing our steps, as it were, will likely not return a lake to its original condition: 
restoration often requires a greater reduction in nutrients than the increase that caused degradation. And the end point of restoration may be a different kind of lake. ${ }^{47}$ You can't turn back time; a lake's state will reflect its history. And, indeed, as an historian, I think that to assess our present problems with freshwater quality we badly need to understand their history. So, in my project I am asking: How did our present problems develop? What is the weight of history behind them? How, given their history, might we approach restoring our lakes? And these questions are best answered, I think, through looking at particular lakes. Here I will use histories of lakes Tūtira, Horowhenua, and Taupō.

\section{Lake Tūtira}

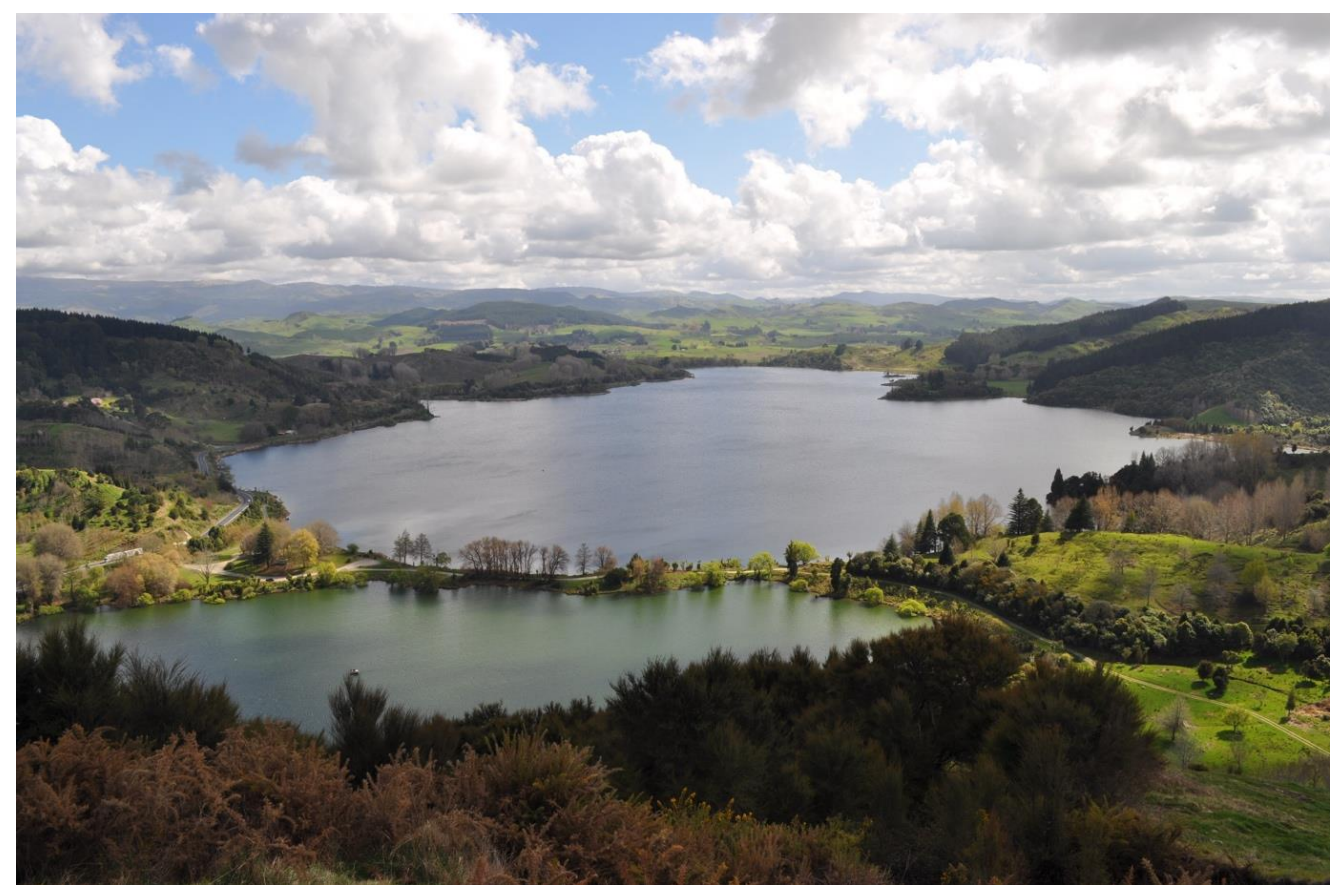

Figure 4. Looking north down Lake Tūtira, with smaller Lake Waikopiro in the foreground; Herbert Guthrie-Smith lived on the west side of the lake.

(Photograph taken 19 September 2019 by the author.)

Lake Tūtira is tucked away in the hill country north of Napier, and skirted by State Highway 2 as it winds to Wairoa. The lake and its catchment were part of the sheep station Herbert Guthrie-Smith took up in 1884, as a young man fresh from England, willing to endure the backbreaking labour of "murdering the sheep and 'making' the country." 48

The house he built still stands on a rise overlooking the lake- for it was the lake which captured his heart from the first:

Before his eyes lay the whole length of the lake, picturesque in its wooded promontories and bays. Along its steeps grew brakes of native woodland brightened at this season with the deep yellow blossoms of the kowhai. The silky leaves of the weeping willows were in their tenderest green, the peach-groves sheets of pink. I have looked at this lovely sheet of water a million times since then, but have rarely seen it more fair. ${ }^{49}$ 
In his 1921 book Tutira: The Story of a New Zealand Sheep Station, Guthrie-Smith described in minute detail what happened to the land as he and his animals reshaped it. In later years he became painfully aware of the damage done. Writing shortly before his death in 1940 he fretted over his "substitution of one flora and fauna for another," his "more quickly melting New Zealand through erosion." ${ }^{\circ 0}$ Now, "when resuscitation and rehabilitation are alike impossible," he famously asked himself, "Have I then for sixty years desecrated God's earth and dubbed it improvement?" ${ }^{11}$ Pleading that "it is impossible for an individual to withstand the stream of tendency," he left it to his readers to decide. ${ }^{52}$ He had no easy answer.

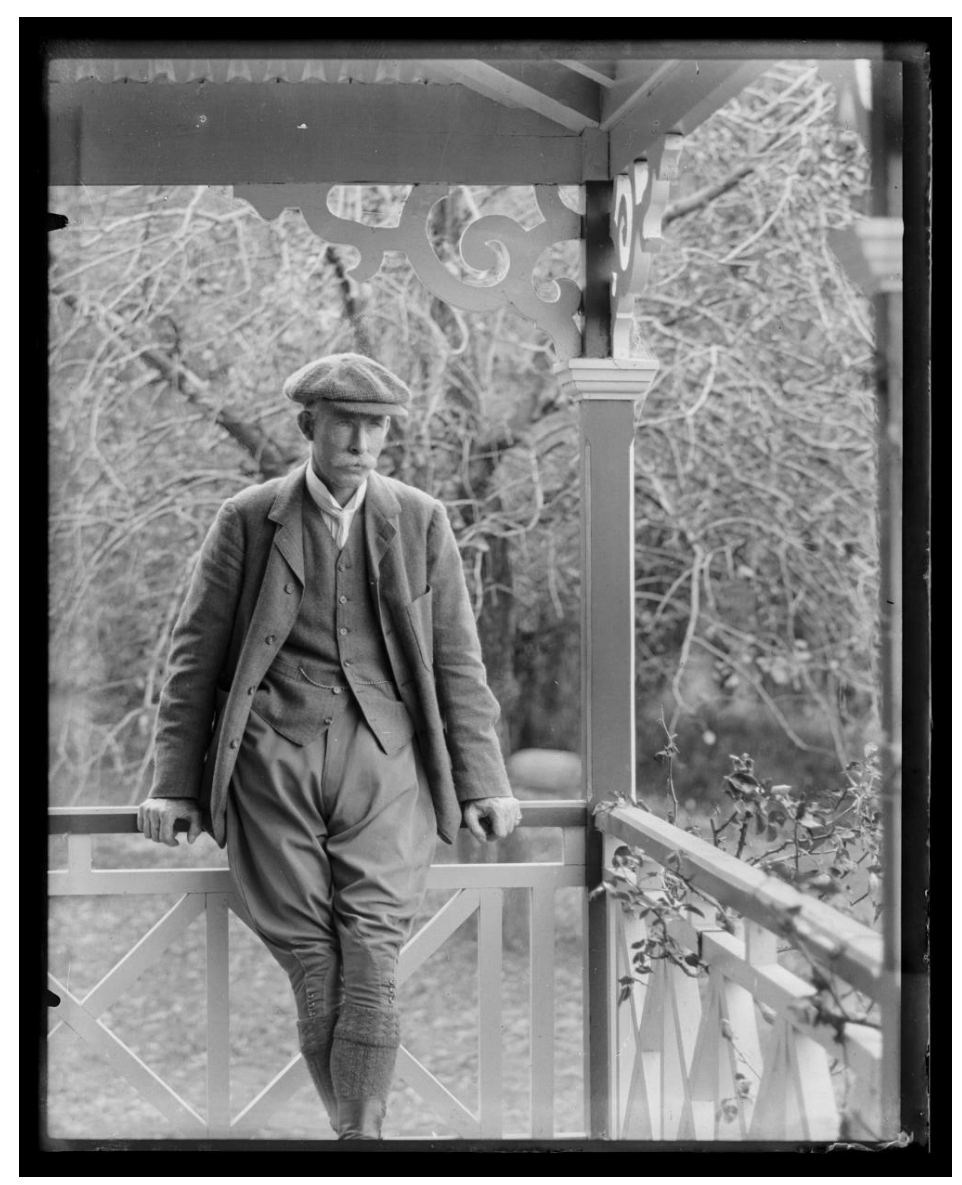

Figure 5. Portrait of Herbert Guthrie-Smith, circa 1930, at his house by Lake Tūtira. (Photographer unknown; the original is held at Te Papa Tongarewa as B.000735; reproduced with permission.)

Herbert Guthrie-Smith understood Tūtira was a microcosm of the whole Pākehā settlement of New Zealand, especially in the North Island where man and sheep together "murdered" so much marginal hill country into pasture. ${ }^{53}$ The immense effort to do this speaks to a settler culture in which the idea any land might lie idle was anathema. As Herbert showed, this has had severe environmental consequences - nowhere more so than at Lake Tütira.

Tūtira lies in a narrow steep-sided valley, and so is quite deep, up to 42 metres. It was formed after a landslide blocked the valley stream some 7200 years ago. ${ }^{54}$ Oddly, Tūtira's inlet and outlet are at the same end, so water lingers in the lake for a long time. ${ }^{55}$ As a result the land's history is beautifully caught in the layers of the lake sediments, capturing the ecological effects 
of storms, earthquakes, and volcanic eruptions, followed by human impacts on the lake's ecology and its water quality. ${ }^{56}$

Sediment core analysis shows Māori had, soon after arrival, burnt off the forest from the surrounding slopes, so that they carried a cover of deep rooted bracken and scrub - almost as effective as forest at maintaining soil stability — until Guthrie-Smith cleared them for grass. ${ }^{57}$

Herbert Guthrie-Smith had leased the land from its Māori owners, largely members of Ngāti Kurumōkihi, a hapū of Ngāti Kahungunu. The hapū knew the lake was the land's focal point. Their settlements surrounded what they named "ko te waiū o ō tātau tipuna"- "the milk of our ancestors." 58 As Herbert concluded, "The glory of the hapu was in their continued occupation of so famous a lake, in their possession of so unfailing a food supply of the most highly prized kind." 59 As many as 16 named eel weirs were found along the stream exiting the lake, while the wetlands on its margins were famed for flax.

However, when Guthrie-Smith arrived, the hapū, as such, no longer owned the lake. Rather, in the wake of Donald McLean's 1867 Hawkes Bay raupatu (confiscation), lake and land were "returned" to a list of individuals now owning "interests" in the land. ${ }^{60}$ Most of those people now lived near the coast at Tangoio, but came up to the lake to harvest food and fibre much as they always had, until after the First World War the government decided that it wanted the land for returned soldiers. Despite significant doubts that the land was good enough, the government went ahead — no land must lie idle — and quickly bought most of the Māori interests. It found this easy, as the Tangoio community was by now impoverished, living in tin shacks with bare earth floors in a flood-prone river valley, with high death rates from typhoid and tuberculosis. ${ }^{61}$

Dividing the land, though, was complicated by the lake. Māori who had refused to sell wanted the lake whole, arguing this was a right protected by the Treaty. The government wanted the lake whole too, for a wildlife refuge, and meanwhile refused all Māori requests for fishing and birding rights. ${ }^{62}$

Eventually, when the land and lake were split in 1928, the government got all but the lake's northern tip. In 1957 the government made its portion of Tūtira a wildlife refuge for birds. ${ }^{63}$ Perhaps unsurprisingly, Māori owners declined to include the last part of the lake that remained in their ownership. ${ }^{64}$

The 1950s were also, however, when the first "algal" blooms and invasive weed growths were observed in Lake Tūtira. ${ }^{65}$ Tūtira was invaded by Hydrilla verticillata, one of the world's worst water weeds, whose 10 metre high underwater forests smother all other plants and make the lake bed a black ooze. ${ }^{66}$ In New Zealand it is found only in four Hawkes Bay lakes, having likely arrived after someone emptied their aquarium. ${ }^{67}$ After years of debate, in 2008 the government put grass carp into the lake to eat out the hydrilla. ${ }^{68}$ This seems to have worked: hydrilla has not been seen in the lake for over two years, and native plants and freshwater mussels appear to be in recovery. ${ }^{69}$ There is a possibility, however, that without the weed the lake is still more vulnerable to the persistent and severe algal blooms that have now plagued it for some seventy years. ${ }^{70}$

Lake Tūtira's algal blooms occur because ever since Guthrie-Smith and his sheep cleared an almost naked land, soil has been sliding into the lake. And since the 1950s aerial topdressing has enriched such soil with phosphorus. ${ }^{71}$ 


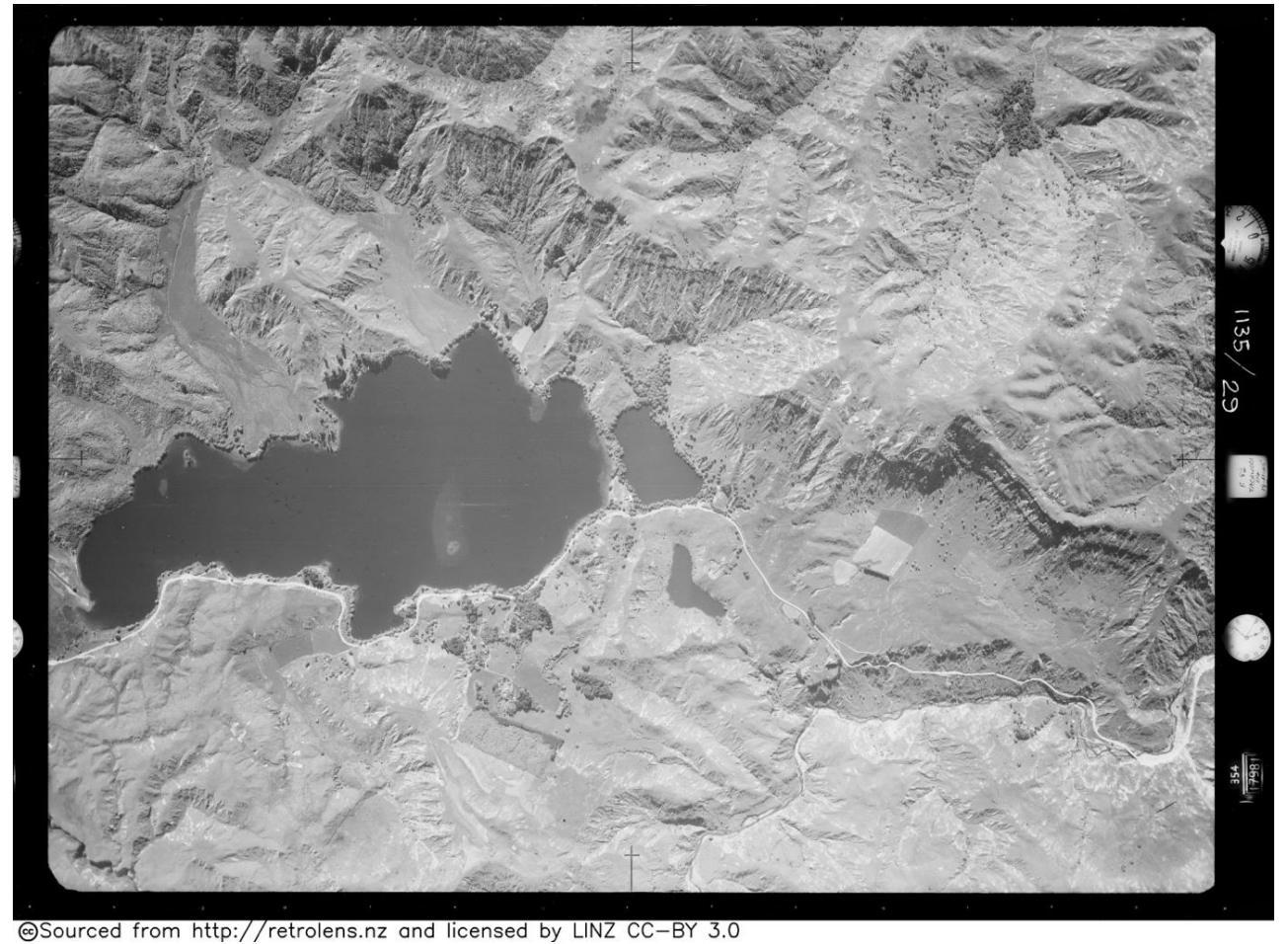

Figure 6. Lake Tūtira and virtually treeless surrounds, as seen from the air, 19 November 1945.

As Herbert foresaw, "The country under my regime has been shorn of its fleece; in the time to come it will be flayed of its very skin." ${ }^{, 72}$ Hawkes Bay has an enviable sunny and generally dry climate, but this is punctuated by extremely violent storms. ${ }^{73}$ Herbert provided graphic descriptions of the erosion they caused: "Tutira, indeed, after a violent 'buster,' appears to have been weeping mud"; "Sometimes a whole hillside will wrinkle and slide like snow melting off a roof." "74 The Anzac Day storm of 1938 deposited almost a foot of sediment on the lake bed. ${ }^{75}$ Fifty years later Cyclone Bola flayed the land as Herbert had feared, pulling 773,000 cubic meters of soil into Tütira, over half of which is still there. ${ }^{76}$

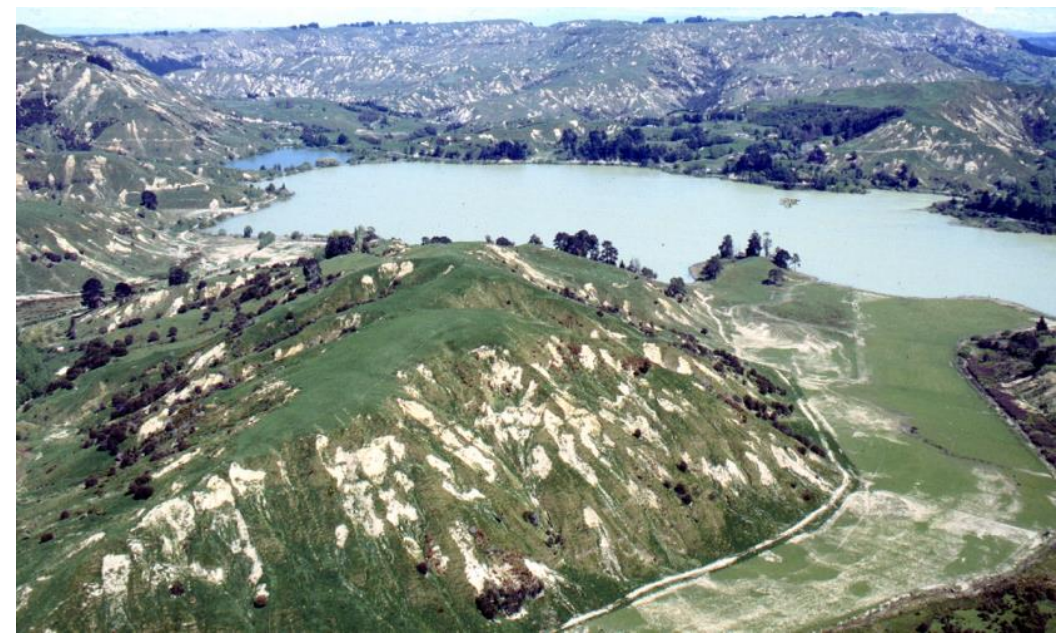

Figure 7. Lake Tūtira and the aftermath of Cyclone Bola scarring the surrounding hills. (Photograph: Philip Trustrum.) 
To understand why Tūtira's algal blooms have persisted since the 1950s we need to delve deeper into limnology, the science of lakes. Scientists are fond of saying lakes are complex. ${ }^{77}$ But Andy Hicks, Principal Scientist at Hawke's Bay Regional Council, gave me a simple hook. "A sick lake", he said, "keeps itself sick." "78 This happens through feedback loops. The best known involves oxygen. Lakes full of nutrients bloom most often in summer, when it is warm and there is lots of light. Then the waters of deeper lakes stratify, so that a surface layer of warmer water (the epilimnion) overlays colder, deeper waters (the hypolimnion), that are isolated from the atmosphere. Oxygen in the depths is gradually consumed by decomposition, especially once the algal blooms crash and die off. Some weed species do the same thing. This rapidly sucks all the oxygen out of the water. ${ }^{79}$ Without oxygen, the chemical bonds binding phosphorus in the lake sediments dissolve. Nitrogen is also released, as ammonia. These nutrients suffuse the overlying water to refuel still more weed and algal growth. ${ }^{80}$ This "internal load" can significantly exceed the external sources of nutrients-for example at Lake Rotorua perhaps by three times. ${ }^{81}$

Weeds and algae can drive a different feedback loop involving $\mathrm{pH}$. Plant growth uses up carbon dioxide, and so drives up $\mathrm{pH}$ levels. Lakes can become very alkaline-fine for bicarbonate adapted species such as invasive weeds and toxic algae, but beyond what native plants can tolerate-while fish from trout and eels to bullies and freshwater mussels are often killed because, under high $\mathrm{pH}$, nitrogen (in the form of an ammonium ion) becomes toxic ammonia gas. ${ }^{82}$ And, when the $\mathrm{pH}$ really rises (to above 9.2), this also dissolves the bonds binding nitrogen and phosphorus in the lake bed, releasing nutrients to fuel yet more growth. ${ }^{83}$ One gram of phosphorus in a lake can sustain around 500 grams of live algae. ${ }^{84}$ And that phosphorus doesn't ever disappear: its atoms just get combined and recombined in different molecules. While that phosphorus is in the lake it has the potential to fuel cycles of growth forever. So, a sick lake keeps itself sick.

Being right beside State Highway 2, Tūtira has long been an accessible and very popular lake for picnics, camping, boating, and fishing. Such visibility has made this sick lake's condition highly embarrassing to the local community (whose children have reportedly been too ashamed to admit they come from Tūtira), and increasingly to the region's politicians. ${ }^{85}$ Community pressure over algal blooms and fish kills led to the formation of the Lake Tutira Technical Committee in 1975 to investigate how to improve the lake's water quality. ${ }^{86}$ It concluded phosphorus inputs needed to be reduced by "a factor of between 5 and 9 times," and its recommendations underpinned a comprehensive plan by the Hawkes Bay Catchment Board to improve lake water quality through land use changes. ${ }^{87}$ In 1981, Tūtira's main tributary, Papakiri Stream (Sandy Creek), was diverted away from the lake and into its outlet, in an effort to cut away the lake's catchment by two thirds. ${ }^{88}$ This was emergency surgery, to disconnect the lake from the most intensively farmed land; it has not been fully successful, however, as the stream still intrudes on the lake during flood events, which is also when its concentrations of nutrients and sediment are highest. ${ }^{89}$ Lake margins were fenced and planted. The Ministry of Agriculture and Fisheries also trialled using air to mix the lake and prevent oxygen depletion in the bottom waters. ${ }^{90}$

Substantial works were planned for the few surrounding sheep farms-retiring erosion-prone land, riparian plantings, and pole planting in willow and poplar. But despite substantial government grants, little was done, as farmers struggling with the removal of agricultural subsidies could spare nothing. ${ }^{91}$ Despite promising results, the air mixer too was mothballed 
for lack of money. ${ }^{92}$ And unfortunately, much of what the scheme had achieved was overturned when Cyclone Bola swamped the lake and the fences and plantings.

In 1998, Hawke's Bay Regional Council started over, buying 463 hectares of the Guthrie-Smith Trust's land on the steep eastern side of the lake for a park "to illustrate to the community how this type of land can best be developed to minimise soil and nutrient loss."

The park has enhanced wetlands and replanted native bush. It has also trialled manuka plantings to see if this can hold the soil and provide some profit (from honey) off such steep hillsides.

Most recently, following settlement of their Treaty claims, Ngāti Kurumōkihi (as part of the broader settling group of the Maungaharuru-Tangitū hapū) have regained ownership of most of the lake bed, and spearheaded renewed efforts at rehabilitation. ${ }^{94}$ They are working well with the regional council, have secured more than 2 million dollars of government funding, and have together developed a new plan for the lake and its catchment. ${ }^{95}$

This plan largely replicates that of the 1980s: the regional council and iwi want to work alongside landowners, avoid regulation and elicit buy in, and manage the catchment through farm plans and plantings. ${ }^{96}$ Meanwhile they aim to aerate the water, destratify the lake, and so hopefully break the feedback loops that fuel the algal blooms. ${ }^{97}$

When I visited, I saw nothing but cooperation and good will. But as Tania Hopmans of Ngāti Kurumōkihi told me: "it's all been kumbaya so far_-but so far no one's had to give anything.,"98

There are now hopes of reconnecting the Papakiri Stream to help flush the lake-but at low flows only. ${ }^{99}$ Land use in that part of the catchment has intensified, and the lake could not take the nutrient load that would come with a flood. ${ }^{100}$ A lot will need to change, Andy Hicks says, before lake and land can be fully reunited. ${ }^{101}$

Herbert Guthrie-Smith spent 60 years transforming the lake's catchment; we have spent almost as long trying to effect some rehabilitation. Even now, options for helping this sick lake are few and prospects remain uncertain. ${ }^{102}$ Tūtira shows us that our present problems with freshwater arise from a deep cultural wellspring: the settler urge to find a way to use and improve land, in the face of all environmental or economic odds. ${ }^{103}$ And Tūtira is a reminder those problems have often been decades in the making. It's said the past isn't dead, it isn't even past. Tütira shows that this is as true of lakes as it is of ourselves. In lakes, as with people, history has an ongoing, ever-recycling legacy. 


\section{Lake Horowhenua}

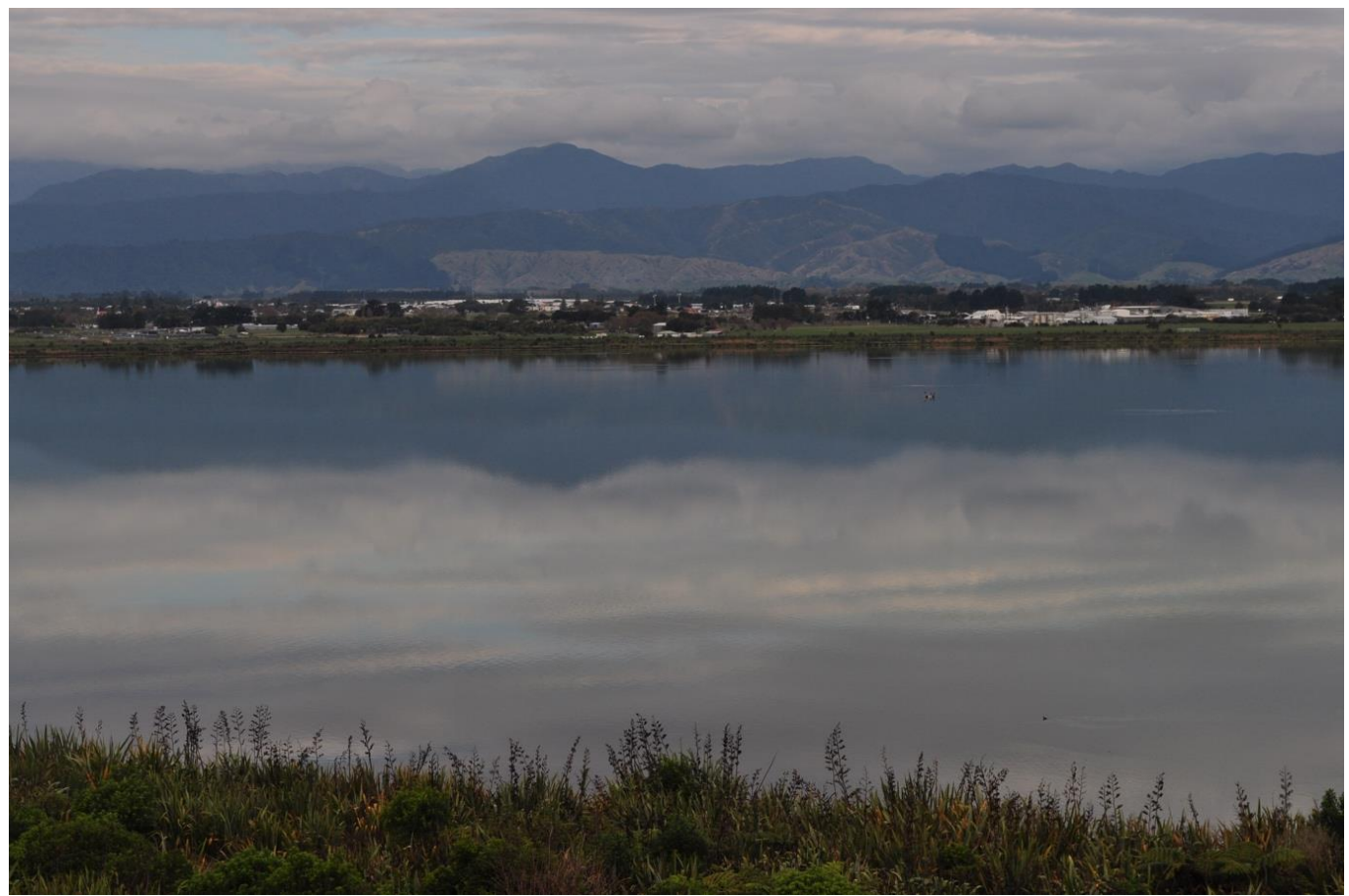

Figure 8. Looking across Lake Horowhenua, to Levin, and the Tararua Ranges.

(Photograph by the author, May 2019.)

Shifting now from Tūtira to Horowhenua, we cross from coast to coast, from a lake set in land sometimes marginal even for sheep, to a water body beside a town, amidst some of the richest alluvial plains soil in the country. Sadly, Lake Horowhenua's history reflects how badly freshwater may fare when exposed to intensive land uses. And, unavoidably, it too has a history of conflict between Māori and Pākehā that mirrors the values these peoples have placed on freshwater.

Lake Horowhenua is a shallow dune lake by Levin, on the plain between the Tararua Ranges and the Tasman Sea. It is the second biggest lake in the lower North Island, after Wairarapa Moana. The lake is part of the heartland of Muaūpoko, who appropriately know the lake as Waipunahau, or Punahau, meaning bubbling springs, for the lake is mainly fed by groundwater flowing through the porous gravels of the plains. ${ }^{104}$ 


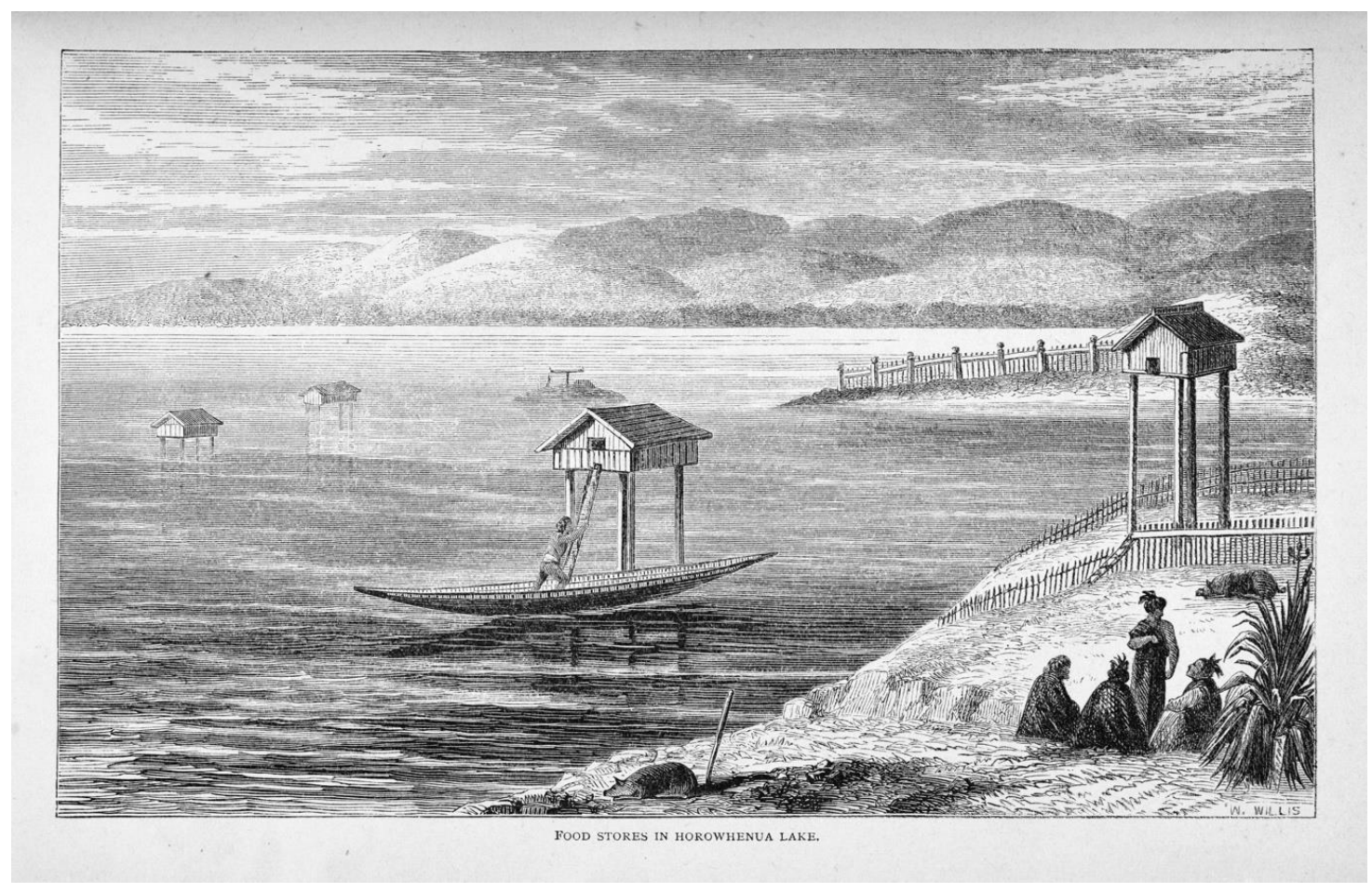

Figure 9: Food Stores in Horowhenua Lake. From Richard Taylor, Te Ika a Maui, or, New Zealand and its Inhabitants (London: Wertheim and Macintosh, 1855), plate opposite page 16.

(Reproduced with permission from the Alexander Turnbull Library.)

Until the twentieth century, Waipunahau was part of "one single large wetland" spanning the Horowhenua's plains, a water world of linked lagoons, swamps and dune lakes. ${ }^{105}$ There, Muaūpoko were "virtually amphibious." water, and Waipunahau was their greatest source of food, and most important home.

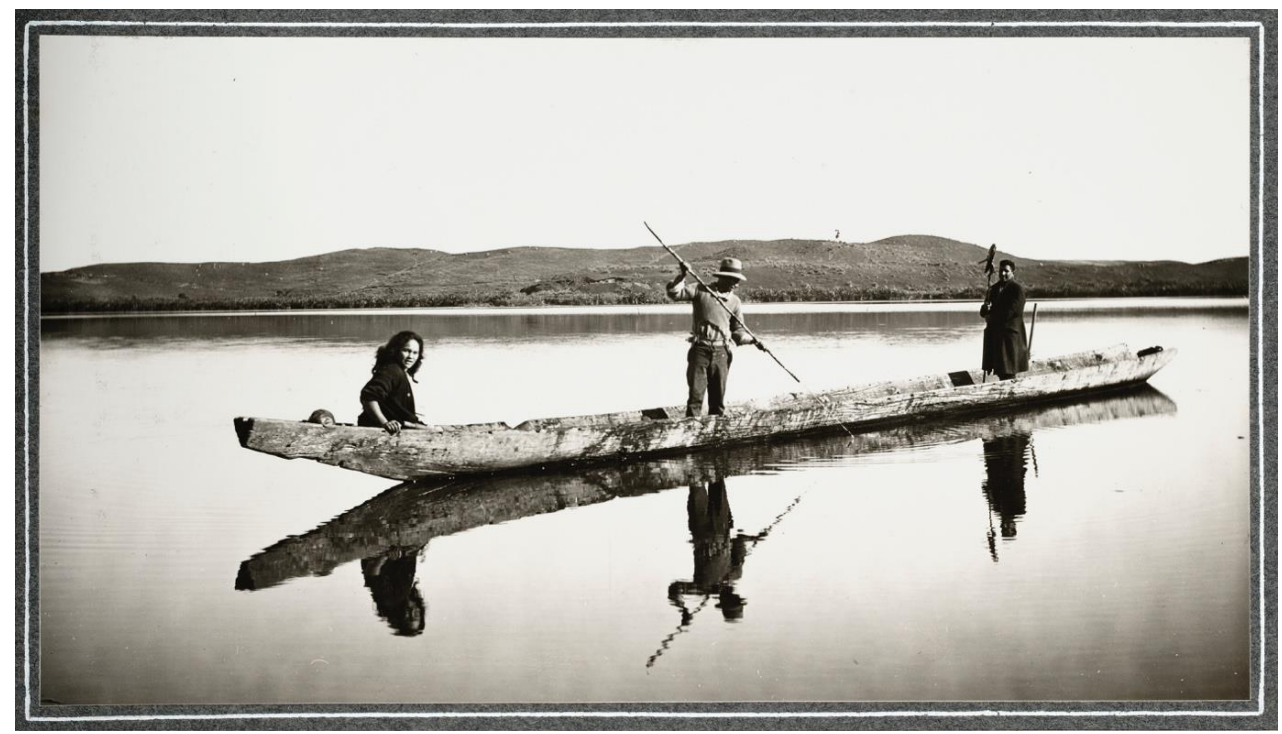

Figure 10. Leslie Adkin's encounter with the Taueki whanau, eeling on Waipunahau from the Haumaria, sparked his desire to record the Māori history of the land and waterways. (Reproduced with permission from the Alexander Turnbull Library, Adkin collection, PA1-q-002 on page 15.) 
Water's centrality in the Horowhenua is hard to see today. Geologist and ethnographer Leslie Adkin thought that "Probably in no other part of New Zealand - since the impact of European civilisation - has the aspect of the territory changed in so many respects to a greater extent than in Horowhenua." 107 When Levin was founded in the 1890s it was called "sawdust town" due to the speed at which the vast sea of trees on the plain was being deforested. ${ }^{108}$ Then the land was drained. Now the fertile floodplains grow cows and cabbages.

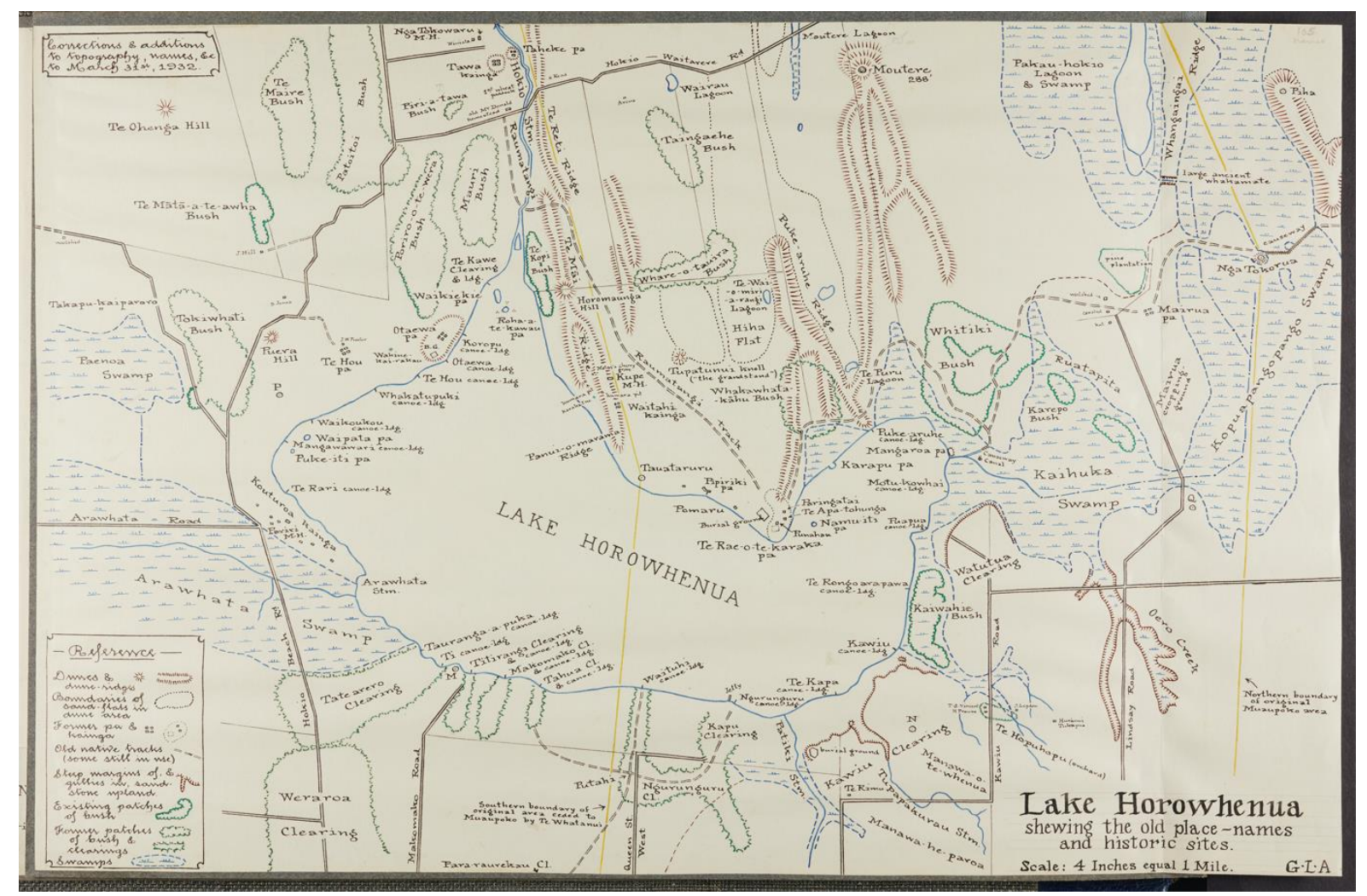

Figure 11. Leslie Adkin's map of Lake Horowhenua highlights the density of Muaūpoko occupation and use of the lake and its shores, showing 7 island pa built on the lake itself, with villages, cultivations and canoe landings on its shores. (Reproduced with permission from the Alexander Turnbull Library, Adkin collection, PA1-f-009-05, album 27, page 5.)

Muaūpoko still own Waipunahau. However, Levin's settlers have fought for control of the lake almost since the Muaūpoko rangatira Te Keepa Rangihiwinui (Major Kemp) agreed to the town being founded. ${ }^{109}$ The government has played referee, reluctantly, and largely ineffectually. ${ }^{110}$ From 1905, when Premier Richard Seddon, the Levin settlers and Muaūpoko apparently reached an agreement in a tin shed by the lake, it has been subject to confused and confusing management through a domain board split between local bodies and Muaūpoko. ${ }^{111}$

In essence, those management arrangements have been meant to protect Māori fishing rights, as well as provide for public recreational use. There has always been tension balancing between such uses. The worst conflicts have revolved around drainage and pollution.

After a hard fight, Levin's settlers in 1926 succeeded in lowering the lake, to run cows on land around the edges. Lowering the lake devastated kakahi beds and spawning grounds, and depleted fisheries. ${ }^{112}$ 


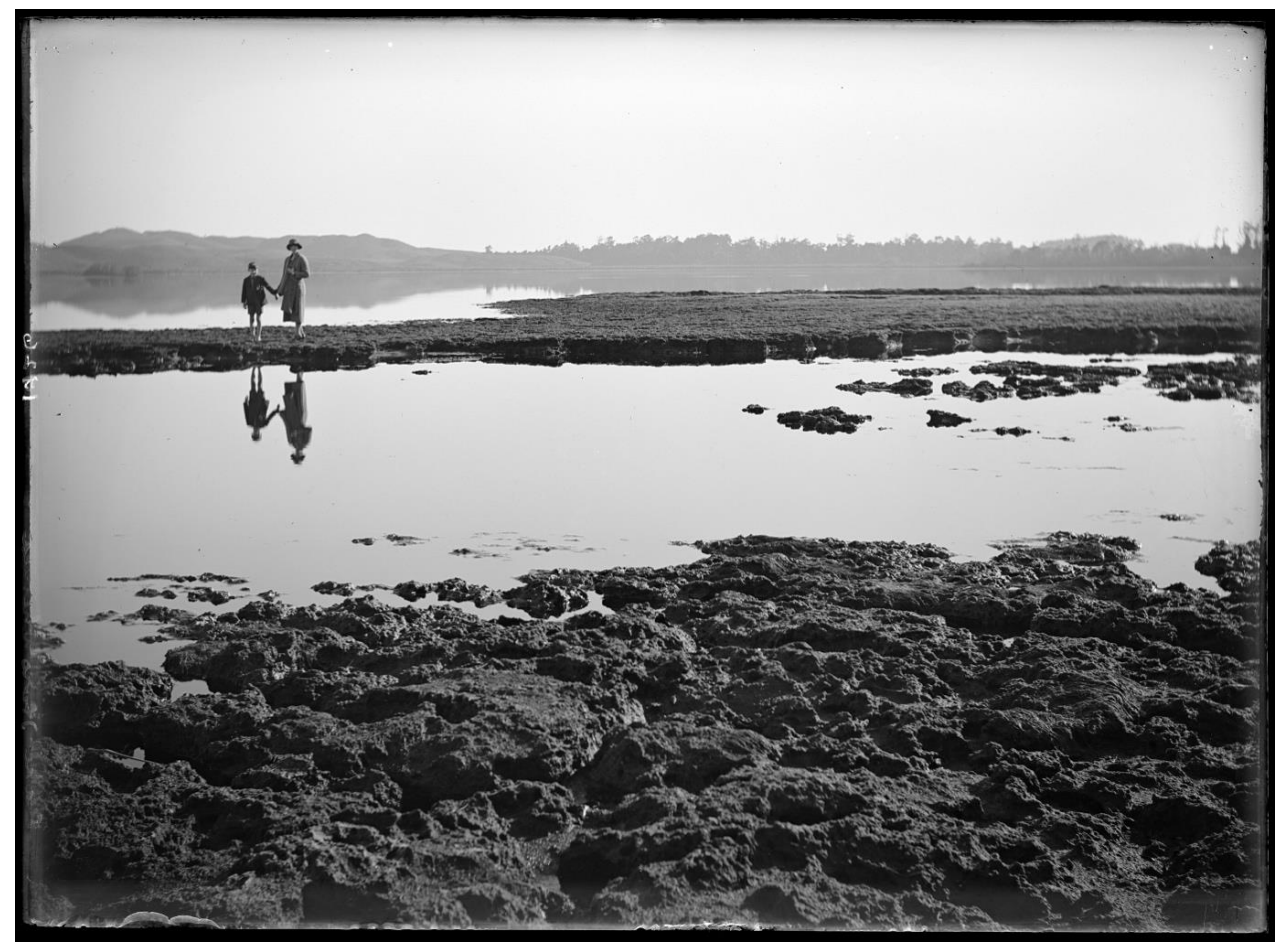

Figure 12. Bed of Lake Horowhenua after lowering of lake level, 8 June 1926. (Photograph by Leslie Adkin; the original is held at Te Papa Tongarewa as B. 020907; reproduced with permission.)

Under a 1950s agreement and subsequent legislation in 1966, a weir was built across the lake's outlet, the Hokio Stream, to hold the lake at this level, to satisfy Levin's desires for better drainage. ${ }^{113}$ This weir, still in place, has blocked the passage of diadromous fish (whose lifecycles involve moving between salt and freshwater), and has meant the lake's sole outflow ceases in some dry years, and made the lake a giant sediment trap. ${ }^{114}$ In Max Gibbs's words, the weir represents eutrophication by Act of Parliament: it has only exacerbated the effects of pollution flowing into the lake — of which there have been all too many sources. ${ }^{115}$

Most notoriously, Levin's sewage effluent all went into the lake between 1953 and $1987 .{ }^{116}$ Less well known, but perhaps almost as bad, a big abattoir fed virtually untreated offal wastes into the lake between the 1930s and the 1970s, as did cowsheds and piggeries. ${ }^{117}$ And a lot of stock used to wallow in the lake. ${ }^{118}$

Levin still drains its stormwater into the lake. The little Arawhata and Pātiki streams flow there through farms and market gardens making full use of the Horowhenua's fertile soils; they are among the country's most nitrogen-polluted waterways. ${ }^{119}$

Lake Horowhenua is a notorious ecological disaster, a "lake of shame" rated hypertrophic, the worst possible measure of freshwater quality. ${ }^{120}$ Filling with sediment, choked with weeds in winter, frothing with toxic algae in summer, it has resembled a stinking stagnant pond for more than 50 years. 


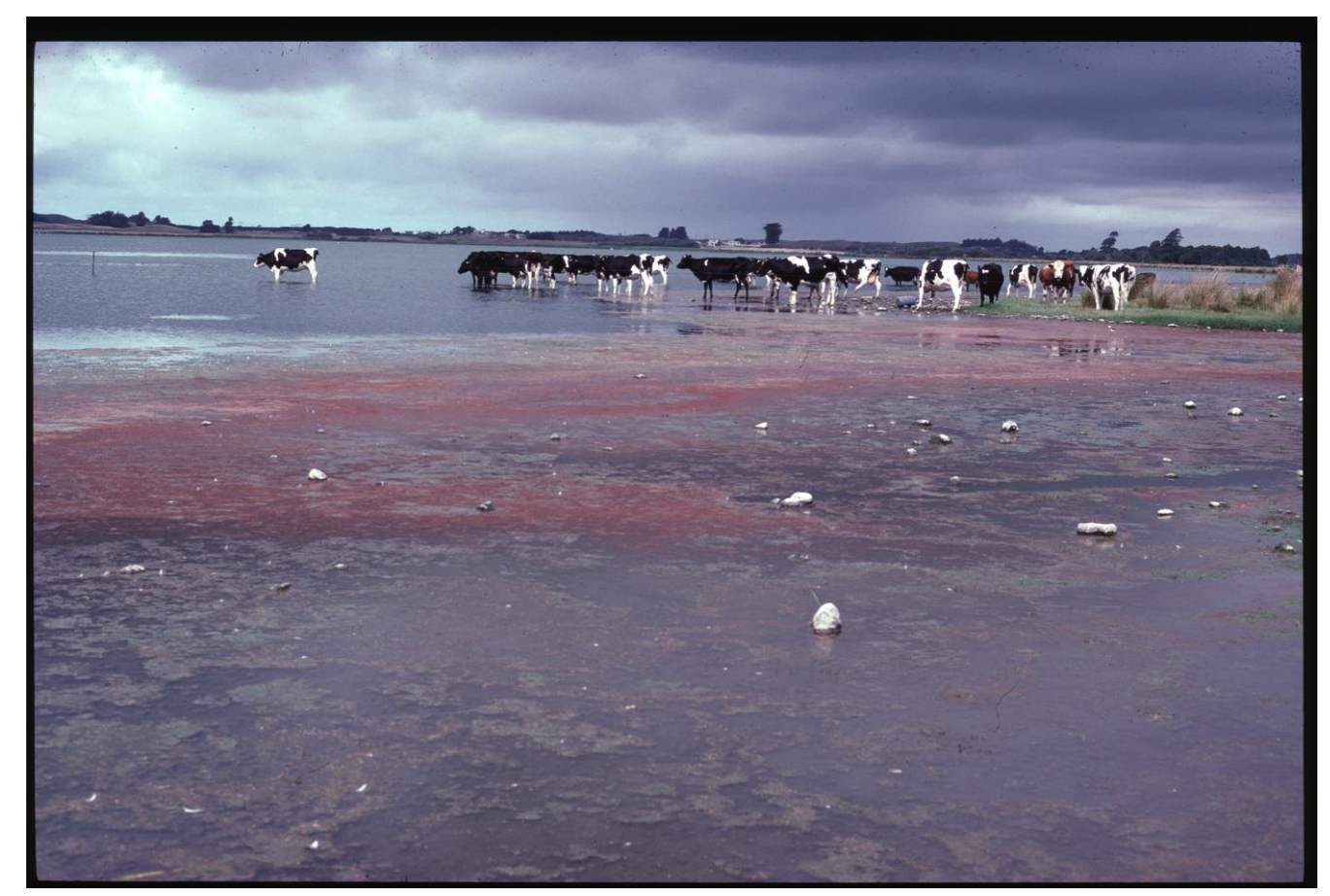

Figure 13. Cattle in the lake in the 1980s, in the midst of a red algal bloom.

(Photograph: Max Gibbs.)

Levin does not advertise its location by the largest lake on the North Island's west coast; only a yellow AA sign tacked to a lamp post points you to the lake. Levin has good reason for its silence and its shame. For the worst acts of pollution were Levin's decisions to put the sewage effluent into the lake and keep it there so long. Those are also the best illustrations of the terrible relationships between the town, the Crown and Māori, concerning the lake's management. Levin had always had problems with where to put its sewage, and by the 1940s an unhappy Health Department compelled action. It was no secret the town wanted to build a treatment plant by the lake, and then dig a drain to pour effluent into it; their problem was Muaūpoko would never allow this. ${ }^{121}$

Sure enough, once they had wind of the council's thinking, Muaūpoko went to Wellington to see the Native Minister, strongly opposed, "first, because it is their property, and, secondly, because an important source of food will be polluted." 122

Health officials, though, decided that Māori fishing rights could be ignored: they had put a bully in a bucket of effluent for a few days, and when it survived they determined there would be no effect on fish. ${ }^{123}$ But plans were changed to avoid having to get Muaūpoko permission for a drain across their land. Instead, Levin's council suggested doing what the adjacent abattoir did-digging big soak pits and draining effluent into them to "percolate away through the ground." 124

As the local Medical Officer of Health explained, this would mean "all the effluent would find its way into the Horowhenua Lake through the soak pits without causing any trouble." The "advantage," he told his superiors, was it "would not be evident at a glance that it is reaching the lake at all and this will obviate the Maoris raising difficulties." 125 So when the sewage scheme was built, Muaūpoko remained unaware all the effluent went underground to their lake. In reflecting on the town's duplicity, it is worth knowing that when Te Keepa agreed to the 
town's establishment, he stipulated this land by the lake be kept sacred, as a garden, jointly held in trust between Muaūpoko and Levin. ${ }^{126}$

Ironically, perhaps, the pits didn't work because they became slick with fats, flooded with groundwater, and overflowed. ${ }^{127}$ Levin found itself awash in sewage in the early 1960s. So the town reverted to their original plan, and started piping the effluent straight into the lake, which they did in the face of trenchant and sustained Māori opposition, till finally forced to pull it out in $1987 .{ }^{128}$

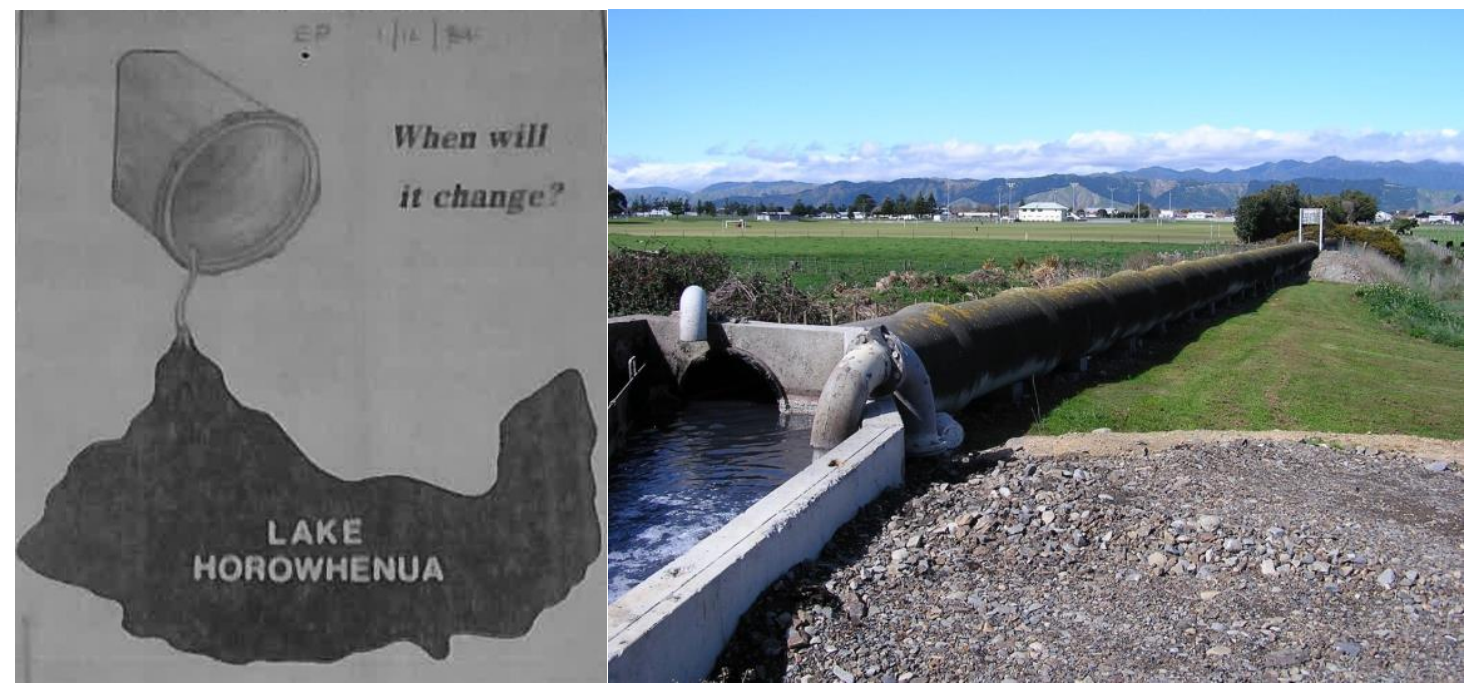

Figure 14. [Left] Evening Post cartoon, 1 December 1984 (Clipping on file AAUM W4043 Box 221 NRS 3/6/Z 1, Archives New Zealand); [right] Sewage effluent pipe into the lake.

(Photograph: Anthony Dreaver.)

Scientists such as Helen Hughes, then working at the DSIR, later our first Parliamentary Commissioner for the Environment, presented data showing the lake was then the most eutrophic in the country - but still thought the lake would recover once the sewage and other point source pollution had stopped, for this was over 90 percent of the nutrients then flowing into the lake. ${ }^{129}$ However, the lake is still in a parlous state. Hughes had not taken account of hysteresis. She underestimated the power of the feedback loops-how sick lakes keep themselves sick - and did not anticipate those loops being activated by intensifying land use around the lake.

Market gardening for winter greens has increased massively, mainly down in the Arawhata catchment, the lake's major tributary. ${ }^{130}$ So their crops are ready just when the supermarkets need them, market gardeners apply huge amounts of nitrogen fertiliser. ${ }^{131}$ Nitrogen leaching off their land near Levin has been measured at $215 \mathrm{~kg}$ per hectare per year-five or six times what comes off the typical dairy farm. ${ }^{132}$ Nitrogen levels in the Arawhata Stream can be toxic to human health, let alone ecosystems. ${ }^{133}$ And dairying has become more intensive. Aquatic chemist and limnologist Max Gibbs of NIWA, who has done much of the recent work on the lake, tells me if you allow more dairy farming immediately east of the lake, then the high oxygen demand required to decompose the dairy effluent might make the groundwater anoxic. This would release all the phosphorus bound in the gravels through which the groundwater seeps to the lake. Then the lake will suffer a continuous and possibly irreversible algal bloom. ${ }^{134}$ 
What if anything is being done to turn all this around? As with Lake Tūtira, there are no easy fixes. Also as at Tūtira, there are accords between local councils and iwi to work to improve the lake, involving better farm and gardening practices. ${ }^{135}$ Unlike at Tūtira, disagreements amongst and between iwi and councils are hampering progress. Horowhenua's then mayor, Michael Feyen, lamented his own council's behaviour, as well as that of the regional council, Horizons, telling me: "the amount of divide and rule I see in this district is heartbreaking. Because it doesn't progress anything at all."136

The lake cannot afford anything but total commitment, because its prognosis is bleak. Max Gibbs estimates without intervention it will take 100 years to clear the legacy of past abuse from the lake bed. ${ }^{137}$ That's why we should be prepared to try emergency measures-most likely dosing the lake with alum (aluminium sulphate) to lock up its phosphorus. Regardless, we still have to stop more nutrients flowing in, which is above all a matter for the regional council, which is where its infamous One Plan comes in.

When Horizons released the One Plan back in 2007, it bravely proposed limits on nitrogen leaching from intensive land uses-dairying, horticulture, and irrigated sheep and beef farming - in 34 catchments, including Lake Horowhenua. ${ }^{138}$ Environmentalists were enthusiastic; farmers and growers were apoplectic. They warned of "farmageddon."139 Horizon's rewrote the plan, backed off regulating anything other than dairying, and dropped some catchments - including that of the lake.

DOC and Fish and Game took the council to the Environment Court. Fonterra, Federated Farmers, Horticulture New Zealand, and Ravensdown Fertiliser lined up to oppose them. These groups emphasised education and said more science was needed to understand agriculture's "actual effects on water quality."

In 2012, the Court threw the farmers' arguments out and scolded Horizons for having agreed with them. The Court commented that the fact that the problems are complex is "absolutely not a reason to say ... it's too hard . . . and do nothing." "141 In 2017, the court told off Horizons again for not implementing its own plan, and instead handing out consents to anyone providing they showed some signs of improvement. ${ }^{142}$ Horizons is now rewriting the One Plan.

The One Plan saga — far from finished after 12 years - says so much about how laborious our planning system is. It also highlights how policy pressures collide head on in a place like Horowhenua. The National-led government aimed to use its soils to help double primary sector exports by 2025, and accommodate urban development to address a housing crisis, in a town growing fast as huge new motorways cut travel times to Wellington; meanwhile the council must maintain or improve water quality. ${ }^{143}$

Originally, the One Plan aimed to improve water quality and provide a pathway for intensifying land use. But best practice on current land uses won't meet water quality targets in Lake Horowhenua or its inflows; not even close. The lake needs nutrients to be three or four times lower just to reach the bottom of the national bottom lines in the Freshwater National Policy Statement. ${ }^{144}$

As Nic Peet, Horizons' Manager of Strategy and Regulation has acknowledged to me, "it may be time we have less intensive horticulture in the catchment, and we shouldn't shy away from 
that." But how much and how fast a change, Nic says, is "a conversation the community still needs to have." 145 What chance Horizons leads that conversation? Well, when the court told Horizons it couldn't just hand out consents to farmers and gardeners promising to do better, its chair Bruce Gordon went to the press to say the decision threatened "wiping out horticulture" in the Horowhenua and meant "\$15 cabbages." 146

To conclude: the fate of Waipunahau to date shows how incompatible freshwater and intensive land use can be. This is, at bottom, a matter of eels and fish versus cows and cabbages: of two cultures, not always reconcilable.

\section{Lake Taupō}

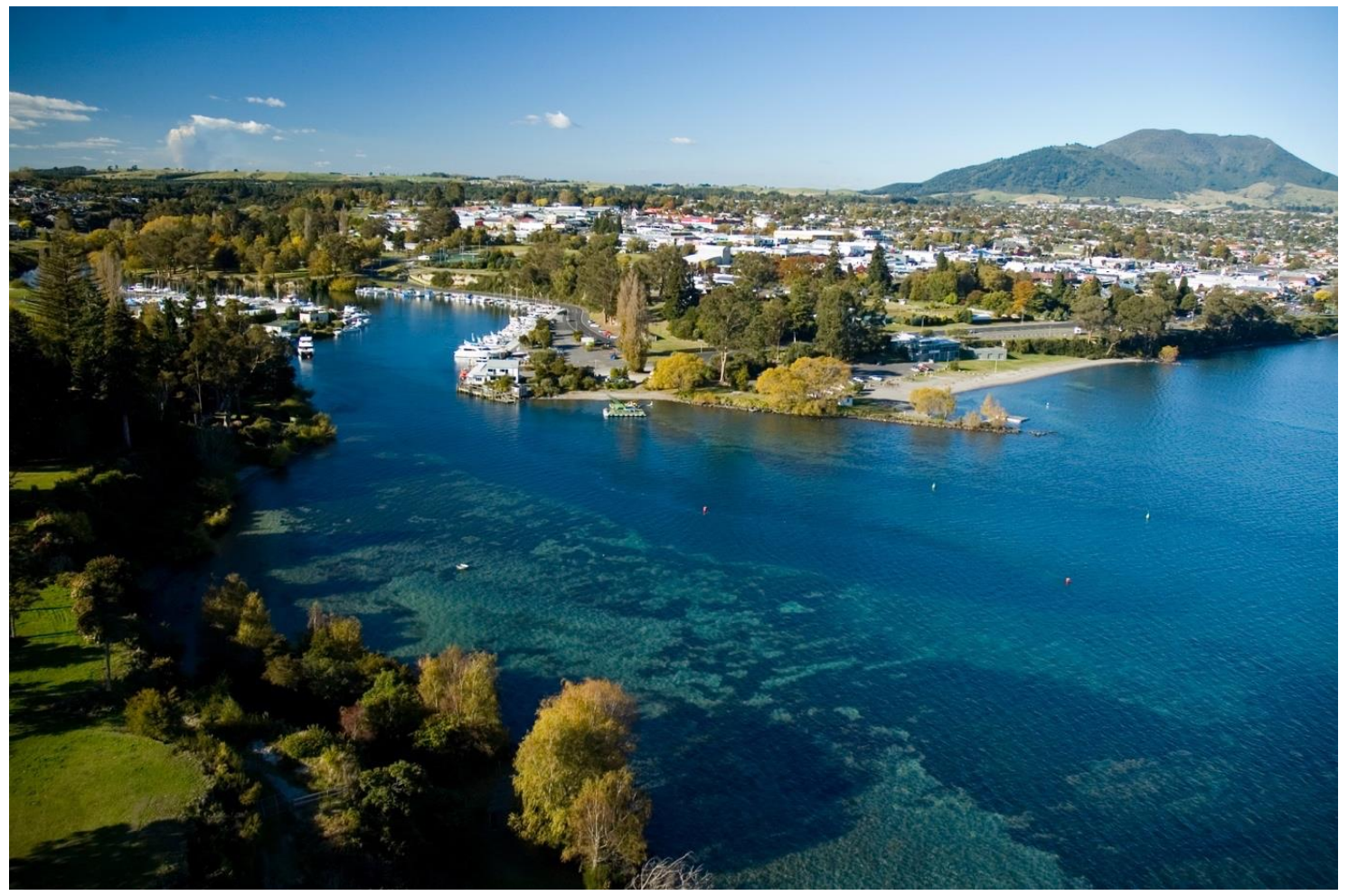

Figure 15. The crystal clarity of Lake Taupō is what people value above all. Taupō township looking towards Mount Tauhara. (Photograph: Waikato Regional Council.)

I want, finally, to venture points of comparison with Lake Taupō. This national icon is our poster child for freshwater protection. Taupō town was founded in 1869-exactly 150 years ago - as an armed redoubt to command the central North Island. In J. D. Ormond's words, so "ends the supremacy of the Maori King."147

Taupō is of course big, at some 620 square kilometres the largest lake in Australasia, and it has a large catchment too, of some 2829 square kilometres. ${ }^{148}$ But development of that land foundered for a long time, on isolation and the bush sickness that stock suffered from as a result of living on pumice soils. Following the discovery that cobalt deficiency caused "bush sickness," which could be cured by applying cobalt in superphosphate, the government fasttracked development of some sheep and dairy farming south of the lake either side of World War II. ${ }^{149}$ But by the 1960s the government still regarded the Taupō catchment overall as the largest block of undeveloped land in the country. 
Local authorities could see a wave of population and development of hundreds of thousands of acres about to wash over them. At the same time, they were all too aware of the dramatic deterioration being seen in the Rotorua lakes.

In 1965, the Taupo County Council went to government, and out to the New Zealand public too, saying Taupō's "most priceless asset is its crystal-clear water," and arguing that the "preservation of absolute purity" was in the national interest. To achieve this the Council had a bold proposal, asking for government leadership in reserving 50,000 acres around the lake and along its streams. ${ }^{150}$

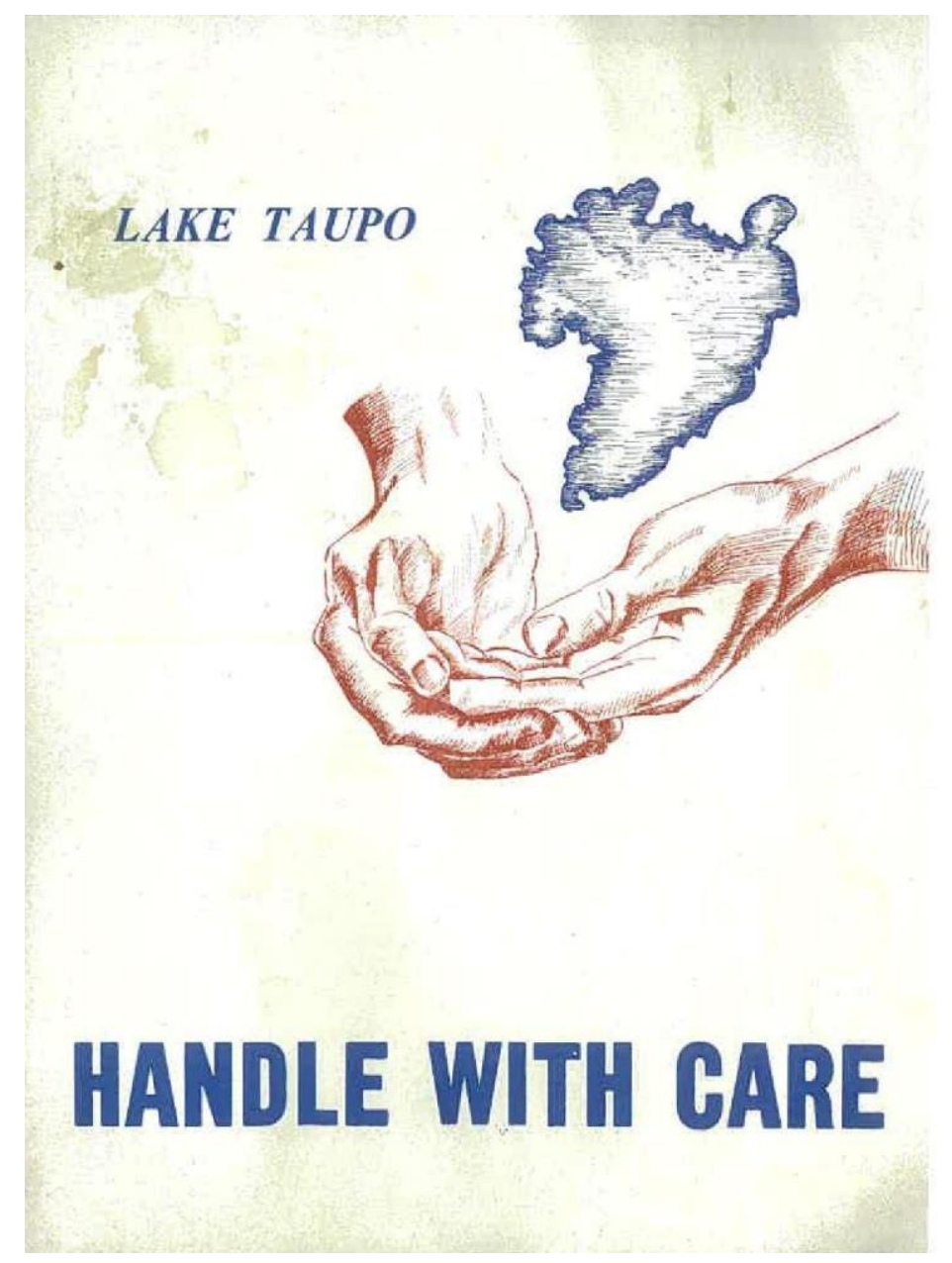

Figure 16. The cover of the Taupo County Council's 1965 publication presenting proposals to preserve the lake. (Photograph by the author.) 
These proposals were seen by many in government as novel, grandiose, and counter to the long-standing ideology of improvement. The local Conservator of Forests D. Kennedy, for example, was apoplectic: the "sterilisation" of the land under reserves should be "resisted with all the emphasis combined with dignity that such an illogical proposal deserves." For, he continued, "This is New Zealand's largest remaining undeveloped area, demonstrably capable of high production . . . almost regardless of the wishes of its owners there is the obvious need to realise its productive potential as soon as possible." ${ }^{151}$ However, others shared the Taupō council's self-conscious awareness that development around Taupō was a belated rerun of New Zealand's original settlement - and there was a determination to do better. ${ }^{152}$ The government agreed to investigate, and subsequently proposed reserving 38,000 acres. ${ }^{153}$

Ngāti Tūwharetoa still owned much of the Taupō catchment - but were not privy to the local and central government committees debating the future of their lands. They were understandably irritated at the government's presumption. ${ }^{154}$ Nevertheless, after some years of wrangling, the government and Ngāti Tūwharetoa agreed to put a stay on development, while the government worked to arrange the reserves, forming many of them from existing Crown land, but buying private land on a willing seller basis. The great bulk of the private land22,000 acres-was owned by Ngāti Tūwharetoa. ${ }^{155}$

The Taupo Basin Coordinating Committee was created to oversee the creation of the proposed reserves. At its first meeting in December 1968 the point was made that they were charged with enacting a solution to an undefined problem. Just how much of the catchment, members asked, "could with safety, be developed for pastoral use?"156 The government was pressed for research on this. ${ }^{157}$ And rightly so. Having agreed to the reserves, and subsequently, in the early 1970s, to substantial riparian planting and fencing in the catchment led by the Waikato Valley Authority, the government was again driving major development schemes for sheep and beef north and west of the lake. ${ }^{158}$ It would continue balloting farmers onto these into the 1980s. All this was behind Eddie White's moving the DSIR Freshwater division to Taupō in 1973. As he warned, "unless a careful watch was kept, enrichment of the lake would inevitably be accelerated." 159

As outlined earlier, the key insight that Eddie and the large team assembled at Taupo reached over the next decade was confirming the nitrogen limitation of many New Zealand lakes, epitomised by Taupō.

One of those mentored by Eddie was Bill Vant, now the guiding light for freshwater science at Waikato Regional Council. Bill told me he raised a red flag when, in 1997, MAF made a map showing hundreds of square kilometres of land around Taupō that could be converted to dairy. ${ }^{160}$ And by 1999 it had become clear that existing activity was already causing some deterioration. ${ }^{161}$ Bill's work has shown just how vulnerable Taupō's precious purity is: there is an initially precipitous fall in water clarity as nutrients - and hence algae - are added to the lake. ${ }^{162}$

So, in 2000, the Waikato Regional Council went to the community, just as the Taupo County Council had 35 years before, to announce there was a problem, and that a plan was needed to protect Taupō and keep it pure. ${ }^{163}$

After a decade of negotiation and court action between landowners, iwi, local and central government, a world-first solution was achieved. Since 2011 a cap and trade system has 
controlled nitrogen discharge to the lakes. (This is also what is planned for Lake Rotorua, whose scheme, at time of writing, has only one final environment court hurdle). ${ }^{164}$ The whole of Taupō catchment's nitrogen discharge to the lake is now capped. Each landowner has an inherited-" "grand-parented" - allowance they have to operate within. To intensify, they have to trade for nitrogen from someone else, who then has to reduce their nitrogen use by an equal amount. ${ }^{165}$ Meanwhile, to help offset expected increases from the delayed effects of land intensification (due to the time it takes for groundwater to percolate through the land to the lake), $\$ 81.5$ million dollars of central and local government funding paid for 13,500 hectares to change from farm to forest. ${ }^{166}$

The scheme is much lauded. There's understandably a great deal of pride in it. It certainly required determined and excellent leadership, from all parties-government, councils, iwi, and farmers. Thanks to Eddie and his successors there had been decades of research into the lake, so it was hard to argue with the science. And it all still went to court, because though the catchment's stakeholders had achieved almost complete agreement, once others realised the significance of it as setting a precedent, they stuck their oars in. ${ }^{167}$

In August 2019, I visited Mike and Sharon Barton on their Taupō beef farm, which in 2005 they bought off a farmer balloted on by the government 20 years before, now despairing of his prospects. Mike told me they were the only people to buy into the catchment in that whole decade of uncertainty - and said they did it because they saw New Zealand's freshwater and farming collision coming and wanted to be part of the conversation from the beginning. ${ }^{168}$ Mike and Sharon are exemplary farmers - they've never used bag nitrogen; they have a major longterm Landcare research programme on their land to test its nitrogen leaching. In fact, Mike speaks a whole new language: he runs his farm by counting money made per kilogram of nitrogen leached. He and Sharon started Taupō Beef, which now markets premium meat from a dozen Taupō operations as farmed sustainably under the nitrogen cap, hormone free, pasture fed-environmentally ethical beef. ${ }^{169}$

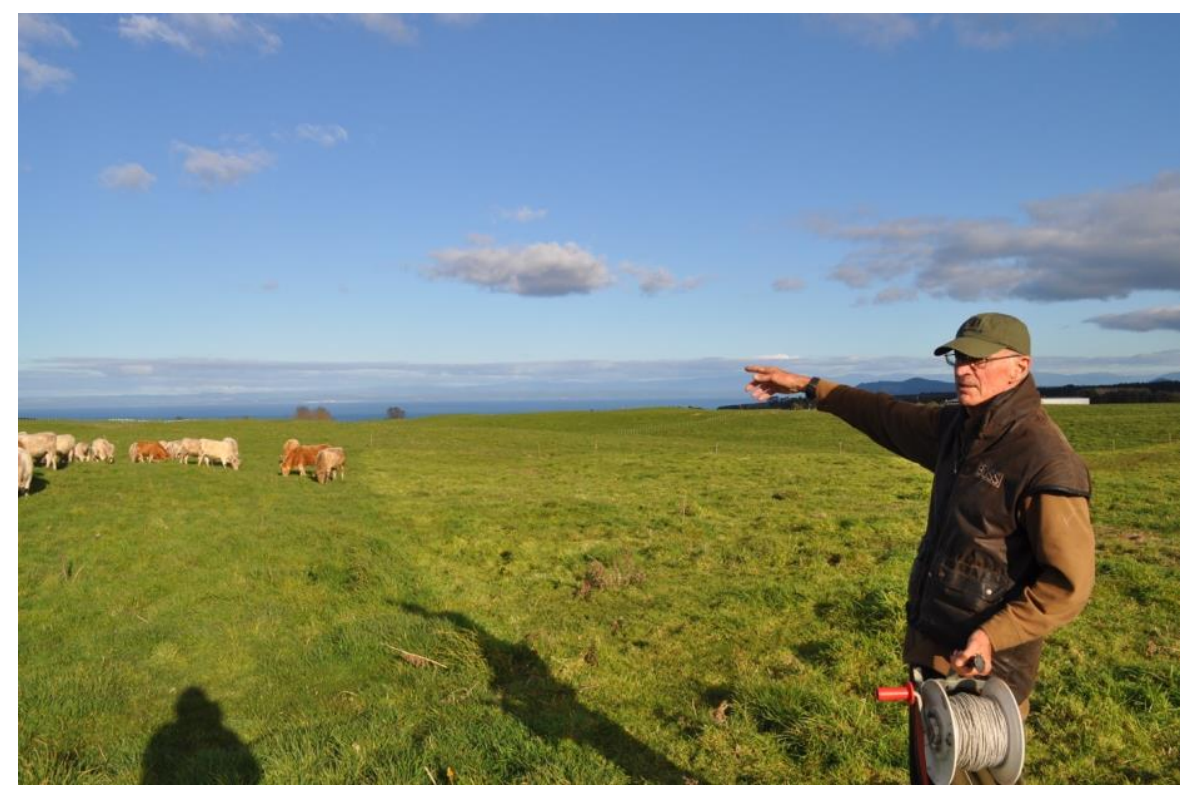

Figure 17. Mike Barton points past his Charolaise Angus beef cattle towards Lake Taupō. (Photograph by the author, taken 28 August 2019.) 
But, Mike points out, that still doesn't fully compensate for lost land values, or the lost opportunity to grow what they could without the cap. The cap's arrival fortuitously coincided with a leap in beef and lamb prices - after 25 years of prior stagnation. Mike's economic modelling suggests when prices fall back, and if costs keep rising as they have, then farmers limited by the cap risk going under, and quickly, because they can't service their debt. ${ }^{170}$

And here's the real thing: we have protected Lake Taupō from the potential impacts of farming - but under 20 percent of Taupō's catchment was in pasture. ${ }^{171}$ Under 200 farms were involved. ${ }^{172}$ Only 6 were dairy. ${ }^{173}$ And the land use change required took $\$ 81.5$ million of taxpayers' money. That was only available because this was Lake Taupō (and because the government was so culpable, having driven the development of the catchment). ${ }^{174}$

We have hundreds of polluted lakes whose catchments are mostly in pasture. Choosing to rehabilitate them means dropping nitrogen by much more than 20 percent. The land values, the debt, the loss in production - the stakes - will often be much higher than in Taupō. ${ }^{175}$

Mike Barton emphasises that farmers can't afford to internalise all their environmental costs. At the very least, the costs of transition will have to be shared. We, the consumers, will have to put our money where our mouths are. ${ }^{176} \mathrm{We}$ will have to pay farmers not to pollute. We could pay more for food. But what of the well-being of the poor if fresh produce prices rise? Who would buy $\$ 15$ cabbages? Or, we could subsidise farmers to reduce their footprint. This will strike many New Zealander's as anathema-what about polluter pays? But put yourselves in the shoes of Taupo farmers. The government developed the land and encouraged them to farm the catchment in the 1970s and early 1980s. Then they removed subsidies, overnight. The farmers who survived intensified. That has been the market signal for generations. Government has encouraged it: double our exports, has been their cry. I can understand farmers' difficulty if we now turn around and say, you are the problem, and the solution is all on you.

In short: the lesson of Taupo is not necessarily a hopeful one. It shows us just how hard it was to intervene, and change the course of history, to protect one of our most precious lakes. It's still not clear the attempt to do something similar at Lake Rotorua will survive the courts or succeed in practice if it does. ${ }^{177}$ What chance our other 3800 lakes?

\section{Conclusion}

Lakes are freighted with the weight of their past: they carry the legacies of their history in their waters and their beds. In Tütira or Horowhenua, it is the legacy of decades past, recycling again and again out of the lake bed, that cause the blooms poisoning the present. In other cases, past pollution is still on its way towards a lake - as at Taupō or Rotorua, where the groundwater bearing "the load to come" is seeping slowly towards them. ${ }^{178} \mathrm{We}$ will be feeling the effects of what we have already done around those lakes for at least as many decades to come.

Having suffered at our hands, lakes will stay polluted unless we help them. Restoring even moderately polluted lakes means significant, sustained, expensive interventions. Our worst lakes require drastic emergency surgery. Measures such as spraying chemicals into the water, or introducing alien fish, rightly make us deeply uncomfortable. But we need to do these things to buy time, while we change what we are doing to lake catchments. The scale of this challenge should not be underestimated. 
We have been on a collision course with freshwater in this country for over a century. We can't turn this around overnight. Or in five years. ${ }^{179} \mathrm{We}$ face starker, and more difficult choices. David Hamilton, until recently founding Chair in Lake Restoration at Waikato University, told me his great fear is that, as the scale of the problem emerges ever more clearly, we retreat to decide: which few lakes in each region will we seriously try to save ${ }^{180}$ I too think this all too likely.

Lakes mirror more than the land: for when we look at a lake, who do we see? Lakes are earth's eye, wrote Thoreau, who went to live by Walden pond to see what nature could teach him. ${ }^{181}$ Like eyes, lakes are the focal point of the landscapes around them. They do not merely reflect but refract, as in a prism, the information in the land's archive. Look into a lake, Thoreau thought, and the beholder measures the depth of his own nature. ${ }^{182}$ The state of our lakes mirrors more than the land. Lakes have always shown us ourselves.

I leave the last word to Mike Barton, and one of what he calls his "silage thoughts," chewing the cud, as it were, as he feeds his cattle:

I posed the question recently: How come if food is what has traditionally brought people together - across cultures, across tables, encouraging frank discussion and the exchange of ideas - how come the production of food has so divided city and country? How have we let the debate get so fractured that what has traditionally brought us together is driving us apart. . . ? I don't have all the answers. But what I do know is, if we could talk more openly, we'd find the answers. ${ }^{183}$

No reira, tēnā koutou, tēnā koutou, tēnā tātou katoa.

\footnotetext{
${ }^{1}$ I thank David Hamilton, Bill Vant, Andy Hicks, Max Gibbs, Marc Schallenberg and Benjamin Kingsbury for very helpful comments on drafts of this article. I am especially grateful to the staff and colleagues at the Stout Research Centre for New Zealand Studies at Victoria University of Wellington, for their support and kindness while I was J. D. Stout Fellow.

${ }^{2}$ C. Howard-Williams, R. Davies-Colley, K. Rutherford and R. Wilcock, "Diffuse Pollution and Freshwater Degradation: New Zealand Perspectives," in Issues and Solutions to Diffuse Pollution: Selected Papers from the 14th International Conference of the IWA Diffuse Pollution Specialist Group, DIPCON 2010, ed. Eric van Bochove, Peter A. Vanrolleghem, Patricia A. Chambers, Georges Thériault, Beáta Novotná and Michael R. Burkhart (Beupre, Quebec: 2010) 126; also see reporting of recent opinion polls, for example: https://www.stuff.co.nz/environment/109701626/water-pollutionthe-number-one-concern-for-new-zealanders-in-new-poll;

https://www.stuff.co.nz/environment/113814708/freshwater-quality-the-countrys-most-identifiedenvironmental-issue.

${ }^{3}$ Pathogens are less frequently seen as a problem for lakes, because they decay rapidly when exposed to sunlight in surface waters of lakes. Sediment not only carries phosphorus, but as well its smothering effects can be a problem for freshwater shellfish such as kakahi. These issues are little studied in lakes, as opposed to estuaries. A recent review of evidence for the effects of land use on New Zealand's freshwater found "no published associations between land use and faecal bacteria or sediment in lakes." See Scott T. Larned, Jonathan Moores, Jenni Gadd, Brenda Baillie \& Marc Schallenberg, "Evidence for the Effects of Land Use on Freshwater Ecosystems in New Zealand," New Zealand Journal of Marine and Freshwater Research (2019):

https://doi.org/10.1080/00288330.2019.1695634.

${ }^{4}$ Howard-Williams et al., "Diffuse Pollution," 128.

${ }^{5}$ On hornwort, see for example Fleur Matheson, Mary de Winton, John Clayton and Tracey Edwards, "Freshwater Biosecurity: How Invasive Weeds Affect Lake Sediments and Native Plant Growth,"
} 
Water \& Atmosphere 12, no. 4 (2004): 14-15; on catfish, see most usefully Lakes Water Quality Society, "Trouble Makers: Catfish, Lake Weeds and Nutrients - Complex Lake Systems Restoration," Proceedings Rotorua Lakes Symposium 2017; on Lindavia, see Amy Weaver, "Low-Intensity Land Use in Grassland Catchments: Effects on a Large, Oligotrophic Lake" (PhD diss., University of Otago, 2016).

${ }^{6}$ In his foreword to Lake Restoration Handbook: A New Zealand Perspective, Bill Vant notes that controlling invasive species and re-establishing native species are a dominant theme. This work is the successor to his 1987 Lake Manager's Handbook, which focused on managing water quality, and which treated eutrophication as "the main cause of water quality problems." See David P. Hamilton, Kevin J. Collier, John M. Quinn, Clive Howard-Williams, eds., Lake Restoration Handbook: A New Zealand Perspective (Springer International Publishing, 2019), viii.

${ }^{7}$ For worldwide issues, see V. H. Smith and D. W. Schindler, "Eutrophication Science: Where do we Go from Here?" Trends in Ecology and Evolution 24 (2009): 201-07. For New Zealand, see J. M. Abell, D. Ozkundakci, and D. P. Hamilton, "Nitrogen and Phosphorus Limitation of Phytoplankton Growth in New Zealand Lakes: Implications for Eutrophication Control," Ecosystems 13 (2010): 966-77; C. M. Smith, R. J. Wilcock, W. N. Vant, D. G. Smith, and A. B. Cooper, Towards Sustainable Agriculture: Freshwater Quality in New Zealand and the Influence of Agriculture, MAF Policy Technical Paper 93/10 September 1993, 52-63; also see generally W. N. Vant, ed., Lake Managers Handbook Water \& Soil Miscellaneous Publication No.103 (Hamilton: Water Quality Centre Ministry of Works and Development).

${ }^{8}$ David W. Schindler and John R. Vallentyne, The Algal Bowl: Overfertilization of the World's Freshwaters and Estuaries (London: Earthscan, 2008), 1. The word is derived from the German eutrophe, in turn from the Greek eutrophia.

${ }^{9}$ Smith and Schindler, "Eutrophication Science," 202.

${ }^{10}$ A phrase I borrow from Marcus Vandergoes, of GNS Science.

${ }^{11}$ Parliamentary Commissioner for the Environment, Restoring the Rotorua Lakes: The Ultimate Endurance Challenge (Wellington: Parliamentary Commissioner for the Environment, 2006).

${ }^{12}$ Ministry for the Environment \& Stats NZ, Our fresh water 2017 https://www.mfe.govt.nz/sites/default/files/media/Environmental\%20reporting/our-fresh-water2017_1.pdf; M. Schallenberg, M. De Winton, P. Verburg, D. Kelly, K. Hamill \& D. Hamilton, "Ecosystem Services of Lakes," in Ecosystem Services in New Zealand-Conditions and Trends, ed. J. Dymond (Lincoln, New Zealand: Manaaki Whenua Press, 2013).

${ }^{13}$ Scott Larned, Ton Selder, Amy Whitehead and Caroline Fraser, Water Quality State and Trends in New Zealand Lakes: Analyses of National Data Ending in 2017 (NIWA: Christchurch, 2018), 10.

${ }^{14}$ Ministry for the Environment and Stats NZ, New Zealand's Environmental Reporting Series: Environment Aotearoa 2019 (Wellington: Ministry for the Environment and Stats NZ, 2019), 20. Only 58 lake monitoring sites had enough data to assess the TLI for 2013-17. For critical comment on inadequacies in national data see Parliamentary Commissioner for the Environment, Focusing Aotearoa New Zealand's Environmental Reporting System (Wellington, Parliamentary Commissioner for the Environment, 2019); Office of the Auditor General, Managing Freshwater Quality:

Challenges and Opportunities (Wellington, Office of the Auditor-General, 2019).

${ }^{15}$ N. Burns, G. Bryers, E. Bowman, Protocol for Monitoring Lake Trophic Levels and Assessing Trends in Trophic State (Wellington: Ministry for the Environment, 2000); P. Verburg, K. Hamill, M. Unwin, J. Abell, Lake Water Quality in New Zealand 2010: Status and Trends (Wellington: New Zealand Ministry for the Environment, NIWA Client Report, 2010).

${ }^{16}$ See Charlie Mitchell, "Canterbury's Poisonous Lake Forsyth Kills Sheep, Full of Green Slime," Stuff, 27 April 2016, https://www.stuff.co.nz/environment/79201011/canterburys-poisonous-lakeforsyth-kills-sheep-full-of-green-slime. Max Gibbs and John Quinn, "Restoration Plan for Lake Horowhenua: Collation of Inter-Related Projects," NIWA client report for Horizons Regional Council, National Institute of Water and Atmospheric Research, January 2012, p8 fn1. Gibbs and Quinn note cyanotoxins concentrations in Lake Horowhenua edge water have reached 36,000 $\mu \mathrm{g} / \mathrm{l}$ (micrograms per litre; equivalent to parts per billion), whereas the government's recommended action level is $12 \mu \mathrm{g} / \mathrm{l}$. 
${ }^{17}$ For a useful precis see Office of the Prime Minister's Chief Science Advisor, Professor Sir Peter Gluckman, New Zealand's Fresh Waters: Values, State, Trends and Human Impacts (Wellington: Office of the Prime Minister's Chief Science Advisor, 2017) xxxi, and 34-39. For the best available analysis of nutrient loss from agricultural land use to lakes in New Zealand, see Jonathan M. Abell, Deniz Ozkundakci, David P. Hamilton and Steven D. Miller, "Relationships Between Land Use and Nitrogen and Phosphorus in New Zealand Lakes," Marine and Freshwater Research 62 (2011): 162 75. This study of $101 \mathrm{New}$ Zealand lakes and their catchments found "the proportion of high-intensity pasture in a lake catchment accounted for more variation in our national dataset than any other land use, explaining 38.6\% of the variation in TN [Total Nitrogen] and 41.0\% TP [Total Phosphorus]" (169-70).

${ }^{18}$ See for example Parker's speech as Minister for the Environment to the Forest \& Bird Annual Conference, "A Vision to Restore the Environment," Wellington, 23 June 2018, https://www.beehive.govt.nz/speech/vision-restore-environment.

${ }^{19}$ E. White "Eutrophication in New Zealand Lakes," in Water in New Zealand's Future: Proceedings of the 4th National Water Conference (Auckland: Institution of Professional Engineers, 1982), 14.

${ }^{20}$ The terms of reference for the freshwater section were specifically "to study the causes and effects of eutrophication." See E. White, "Present and Planned Research in Eutrophication," in Proceedings of Press Forum on Eutrophication: Held at the White Heron Caravelle, Rotorua, 27th September, 1972 (Auckland: NZ Fertilizer Manufacturers' Association, 1973), 17. In 1971, White set out a fivepage manifesto for the work of his new division, describing the need to fully understand one lake's ecosystem, and so be able to predict how it might respond to eutrophication. This became Taupō. See E. White, "An Initial Assessment of the Role of the Ecology Division of DSIR in Dealing with the 'Accelerated' Eutrophication of New Zealand's Freshwaters," unpublished report, Archives New Zealand, file AAOQ W3305 Box 122 72/220 Part 1.

${ }^{21}$ This was a correlation first substantiated in New Zealand by R. H. McColl, "Chemistry and Trophic Status of Seven New Zealand Lakes," New Zealand Journal of Marine and Freshwater Research 6, no. 4 (1972): 441-44 especially.

${ }^{22}$ E. White, "Eutrophication in Perspective" in Proceedings of the 16th Technical Conference of the New Zealand Fertilizer Manufacturers' Research Association vol. 1 (Auckland: NZ Fertilizer Manufacturers' Research Association, 1977), 77. When this proposition was discussed by the Officials Committee on Eutrophication, White highlighted the need to estimate how much and for how long intensive land use could be tolerated in a lake catchment. Rob McColl agreed, and felt land use might have to change for some central North Island lakes in particular. They further agreed on the need to develop a model, requiring agricultural data defined by lake catchments. All this presages what has become central to lake science and management in the last few decades. See Minutes of the Officials Committee on Eutrophication, 6 April 1977, Archives New Zealand, file AAAC W3207 Box 15 WIL 3/2/12 8.

${ }^{23}$ E. White "Eutrophication in New Zealand Lakes," 129.

${ }^{24}$ E. White, "Lake Eutrophication in New Zealand-A Comparison With Other Countries of the Organisation for Economic Co-operation and Development," New Zealand Journal of Marine and Freshwater Research 17 (1983): 437-44. Rob McColl, Eddie White's predecessor, has suggested to me that this awakening dates to a 1972 seminar Rob gave in the presence of Noel Hynes, an emminent Canadian freshwater biologist, when Hynes incredulously asked about his measurements of nitrate concentrations in the Rotorua Lakes: "didn't I mean milligrams per litre rather than micrograms per litre!?” Interview with Rob McColl, 20 December 2019. Certainly, Eddie White told the Taupo Basin Coordinating Committee in late 1972 that he thought "nitrogen might be more of a problem than phosphrous" in Lake Taupō. Minutes of the Taupo Basin Corrdinating Committee, 10 November 1972, Archives New Zealand, file AAUM W4043 Box 220 NRS 3/61 Part 1.

${ }^{25}$ The overriding significance of phosphorus loading in the lakes of the Northern Hemisphere was shown by Richard Vollenweider in 1968 and was famously demonstrated by the Experimental Lake Program in Ontario in the early 1970s. See D. W. Schindler, "Eutrophication and Recovery in Experimental Lakes: Implications for Lake Management," Science 84 (1974): 897-99. Eddie White's comments on the differences between the northern hemisphere and New Zealand are set out in "Lake 
Eutrophication in New Zealand-A Comparison With Other Countries." Carolyn Burns has emphasised to me that Eddie White, and following him other New Zealand limnologists, had great difficulty for years in having these findings accepted or published by the wider scientific community. Interview with Carolyn Burns, 17 January 2020.

${ }^{26}$ E. White and M. T. Downes, "Preliminary Assessment of Nutrient Loads on Lake Taupo, New Zealand," New Zealand Journal of Marine and Freshwater Research 11, no. 2 (1977): 354.

${ }^{27}$ E. White "Eutrophication in New Zealand Lakes," 136.

${ }^{28}$ R. H. S McColl and Helen R. Hughes (compilers), The Effects of Land Use on Water Quality: A Review, Water \& Soil Miscellaneous Publication no. 23 (Wellington: Water and Soil Division Ministry of Works and Development for National Water and Soil Conservation Organisation and Officials Committe on Eutrophication, 1981).

${ }^{29}$ For the establishment of the lakeweed committee, see V. J. Chapman, A History of the Lake-Weed Infestation of the Rotorua Lakes and the Lakes of the Waikato Hydro-Electric Scheme, New Zealand Department of Scientific and Industrial Research information series no. 78 (Wellington: Government Printer, 1970), 18-38. The establishment of the Officials Committee on Eutrophication is described in the Minutes of the Interdepartmental Committee on Lakeweed (Eutrophication), 29 July 1969, and in I. Baumgart (for Director-General DSIR) to Secretary-General Internal Affairs, 2 April 1970, which sets out the new committee's terms of reference and membership as agreed by Cabinet (Archives New Zealand, file AAAC W3207 Box 15 WIL 3/2/12 1).

${ }^{30} \mathrm{McC}$ oll and Hughes, The Effects of Land Use on Water Quality, 21-27. Rob McColl tells me they pressed for this to have regulatory force as an NWASCO guideline, meaning it would have the imprimatur of an NWASCO policy statement, and so require regional catchment and water boards to implement it. However, farmers on the NWASCO "drew its teeth so that it never had statutory weight and status in law." Interview with Rob McColl, 20 December 2019.

${ }^{31}$ Minutes of meeting of the Officials Committee on Eutrophication, 5 April 1979, Archives New Zealand, file AAUM W4043 Box 53 ENV 5/1/A 2.

${ }^{32}$ G. W. Butler, Chair Officials Commitee on Eutrophication to Minister of Science and Technology, 12 July 1979, Archives New Zealand, file AAUM W4043 Box 53 ENV 5/1/A 2.

${ }^{33}$ File note of meeting of the Officials Committee on Eutrophication, 5 April 1979, Phillip Tortell, Commission for the Environment, Archives New Zealand, file AAUM W4043 Box 53 ENV 5/1/A 2.

${ }^{34}$ Catriona MacLeod and Henrik Moller, "Intensification and Diversification of New Zealand Agriculture since 1960: An Evaluation of Current Indicators of Land Use Change," Agriculture, Ecosystems and Environment 115 (2006): 212.

${ }^{35}$ Many works describe the work of Fritz Haber and the development of the Haber-Bosch process for synthesising nitrogenous fertiliser. See for example Thomas Hager, The Alchemy of Air: A Jewish Genius, a Doomed Tycoon, and the Discovery that Fed the World but Fuelled the Rise of Hitler (New York: Harmony Press, 2008); Vaclav Smil, Enriching the Earth: Fritz Haber, Carl Bosch, and the Transformation of World Food Production (The MIT Press: Cambridge (MA) and London, 2001). ${ }^{36}$ See "World Population With and Without Synthetic Nitrogen Fertilizers" https://ourworldindata.org/grapher/world-population-with-and-without-fertilizer?time=1900..2015.

37 See for example this map comparing countries' fertiliser use on cropland https://ourworldindata.org/fertilizers\#total-fertilizer. For statistics on New Zealand's fertiliser use since 1990, see https://www.stats.govt.nz/indicators/nitrogen-and-phosphorus-in-fertilisers accessed 20 December 2019.

${ }^{38}$ Parliamentary Commissioner for the Environment, Growing for Good. Intensive Farming, Sustainability and New Zealand's Environment (Wellington: Parliamentary Commissioner for the Environment, 2004); MacLeod and Moller, "Intensification and Diversification," 212-15.

${ }^{39}$ New Zealand's nitrogen balance has deteriorated since 1998 worse than any other country. See OECD Environmental Performance Reviews: New Zealand 2017, (Paris: OECD Publishing, 2017) 159-60, available at http://dx.doi.org/10.1787/9789264268203-en. The national nitrogen surplus has increased at a similar rate to the national dairy herd, the main contributor. Overall, dairy cattle contributed 39 percent of New Zealand's nitrate leaching from livestock in 1990, but 65 percent in 2017. See Statistics New Zealand, "Nitrate Leaching from Livestock," 18 April 2019, 
https://www.stats.govt.nz/indicators/nitrate-leaching-from-livestock. The reasons for and effects of nitrate leaching from dairy farming in New Zealand now has a very large literature. See, just for example: J. R. Dymond, A.-G. E. Ausseil, R. L. Parfitt, A. Herzig and R. W. McDowell, "Nitrate and Phosphorus Leaching in New Zealand: A National Perspective," New Zealand Journal of Agricultural Research 56, no. 1 (2013): 49-59; R. W. McDowell and R. J. Wilcock, "Water Quality and the Effects of Different Pastoral Animals," New Zealand Veterinary Journal 5, no. 6 (2008): 289-96; Kyleisha J. Foote, Michael K. Joy and Russell G. Death, "New Zealand Dairy Farming: Milking our Environment for All Its Worth," Environmental Management 56 (2015): 709-30. Amanda Judge and Stewart Ledgard present especially useful data showing nitrogen leaching over 2002-2003 from MAF-monitored Waikato dairy farms was four times that from sheep and beef farms $(42 \mathrm{~kg} / \mathrm{ha} / \mathrm{year}$ versus $10 \mathrm{~kg} / \mathrm{ha} /$ year, primarily due to massive differences in the use of synthetic nitrogen, with an average $160 \mathrm{~kg} / \mathrm{ha} /$ year used on dairy farms, but only $9 \mathrm{~kg} / \mathrm{ha} /$ year on sheep and beef. See Amanda Judge and Stewart Ledgard, Nutrient Budgets for Waikato Dairy and Sheep/Beef Farms for 1997/98 and 2002/03. Environment Waikato Technical Report 2004/19.

${ }^{40}$ P. Verburg, K. Hamill, M. Unwin and J. Abell, Lake Water Quality in New Zealand 2010: Status and Trends (National Institute of Water \& Atmospheric Research Ltd: Hamilton, 2010).

${ }^{41}$ According to data reported in Verburg et al., Lake Water Quality in New Zealand 2010, lakes Selfe, Hawdon, Grasmere, Sarah, Alexandrina and Camp all had mean TLI scores under 3 between 2005 and 2009, meaning they would qualify as oligotrophic lakes. Since then, I calculate mean TLI scores 2010-2019, based on LAWA data, suggest only lakes Selfe and Alexandrina remain below 3, and then barely.

${ }^{42}$ J. Abell and P. van Dam-Bates, Modelling Reference and Current Trophic Level Index for New Zealand Lakes, consultant's report prepared for the University of Waikato by Ecofish Research Ltd, 6 November 2018, 54-56; also Verburg et al., Lake Water Quality in New Zealand 2010. For data on the causes of this shift see Jonathan M. Abell, Deniz Özkundakci, David P. Hamilton, Paul van DamBates and Richard W. McDowell, "Quantifying the Extent of Anthropogenic Eutrophication of Lakes at a National Scale in New Zealand," Environmental Science \& Technology 53, no. 16 (2019): 943952; T. H. Snelder, S. T. Larned, and R. W. McDowell, "Anthropogenic Increases of Catchment Nitrogen and Phosphorus Loads in New Zealand," New Zealand Journal of Marine and Freshwater Research 52, no. 3 (2018): 336-61.

${ }^{43}$ See the evidence of Alison Dewes in resource management hearings, for example "Brief of Evidence of Dr. Alison Dewes, 3 May 2019," available at https://www.waikatoregion.govt.nz/assets/WRC/Council/Policy-and-Plans/HR/Block2/Beef-LambNZ-Alison-Dewes-Evidence.pdf; "Statement of Evidence of Dr. Alison Dewes on behalf Wellington Fish \& Game Council," available at http://www.horizons.govt.nz/HRC/media/Media/One\%20Plan/Alison-Dewes-20120314.pdf?ext=.pdf. ${ }^{44}$ Likely adverse effects of predicted climate change include increased cyanobacterial blooms, reduced oxygen and increased periods of bottom water anoxia, and greater internal nutrient loading in lakes. See Smith and Schindler, "Eutrophication Science"; for the New Zealand context, see D. Hamilton, D. Özkundakci, G. McBride, W. Ye, L. Luo, W. Silvester, \& P. White, Predicting the Effects of Nutrient Loads, Management Regimes and Climate Change on Water Quality of Lake Rotorua (Hamilton: Environmental Research Institute Report 005, University of Waikato. prepared for Bay of Plenty Regional Council, 2012).

${ }^{45}$ Marc Schallenberg and Brian Sorrell, "Regime Shifts Between Clear and Turbid Water in New Zealand Lakes: Environmental Correlates and Implications for Management and Restoration," New Zealand Journal of Marine and Freshwater Research 43 (2009): 701-12.

${ }^{46}$ P. Gerbeaux, "Potential for Re-Establishment of Aquatic Plants in Lake Ellesmere (New Zealand)," Journal of Aquatic Plant Management 31 (1993): 122-28.

${ }^{47}$ Scott T. Larned \& Marc Schallenberg, "Stressor-Response Relationships and the Prospective Management of Aquatic Ecosystems," New Zealand Journal of Marine and Freshwater Research 53, no. 4 (2019): 489-512; also Larned et al., "Evidence for the Effects of Land Use," 20.

${ }^{48}$ Herbert Guthrie-Smith, Tutira: The Story of a New Zealand Sheep Station (Seattle and London: University of Washington Press, 1999), 139. 
${ }^{49}$ Guthrie-Smith, Tutira, 151.

${ }^{50}$ Guthrie-Smith, Tutira, xxiii. These quotations are drawn from the preface to the third edition of Tutira, written in 1940, shortly before Guthrie-Smith died.

${ }^{51}$ Guthrie-Smith, Tutira, xxiii.

${ }^{52}$ Guthrie-Smith, Tutira, xxiii.

${ }^{53}$ Guthrie-Smith, Tutira, 423.

${ }^{54}$ M. J. Page, N. A. Trustrum, A. R. Orpin, L. Carter, B. Gomez, U. A. Cochran, D. C. Mildenhall, K. M. Rogers, H. L. Brackley, A. S. Palmer, and L. Northcote, "Storm Frequency and Magnitude in Response to Holocene Climate Variability, Lake Tutira, North-Eastern New Zealand," Marine Geology 270 (2010): 30-44.

${ }^{55}$ Residence time was some two years prior to diversion of the Papakiri Stream. It is now some seven years. R. H. S. McColl, "Lake Tutira: The Use of Phosphorus Loadings in a Management Study, New Zealand," Journal of Marine and Freshwater Research 12 (1978): 251-56.

${ }^{56}$ M. J. Page, N. A. Trustrum, N.A. and R. C De Rose, "A High-Resolution Record of Storm-Induced Erosion from Lake Sediments, New Zealand," Journal of Paleolimnology 11 (1994): 333-48; M. J. Page, N. A. Trustrum, "A Late Holocene Lake Sediment Record of the Erosional Response to Land Use Change in a Steepland Catchment, New Zealand," Zeitschrift für Geomorphologie 413 (1997): 369-92; D. N. Eden and M. J. Page, "Palaeoclimatic Implications of a Storm Erosion Record from Late Holocene Lake Sediments, North Island, New Zealand," Palaeogeography, Palaeoclimatology, Palaeoecology 139 (1998): 37-58; M. J. Page et al., "Storm Frequency and Magnitude," 30-44. ${ }^{57}$ Janet M. Wilmshurst, Matt S. McGlone, and Trevor R. Partridge, "A Late Holocene History of Natural Disturbance in Lowland Podocarp/Hardwood Forest, Hawke's Bay, New Zealand," New Zealand Journal of Botany 35, no. 1 (1997): 79-96; Janet M. Wilmshurst, "The Impact of Human Settlement on Vegetation and Soil Stability in Hawke's Bay, New Zealand," New Zealand Journal of Botany 35, no. 1 (1997): 97-111.

${ }^{58}$ See for example Waitangi Tribunal, The Mohaki ki Ahuriri Report (Wellington: Legislation Direct, 2004), 630. Tania Hopmans pointed out to me that as her people liken the lake to their mother's breast milk, the lake's sickness has implications for her people's wellbeing. Interview with Tania Hopmans, 31 July 2019.

${ }^{59}$ Guthrie-Smith, Tutira, 68.

${ }^{60}$ McLean settled the Mohaka-Waikare confiscation block in the Hawkes Bay himself, through agreements reached in 1868 and 1870 with "loyal" Māori. The Tūtira block was returned to 40 named individuals. It was returned as land in fee-simple, but had to be subdivided and surveyed before Crown grants could be issued. Richard Boast, The Mohaka-Waikare Confiscation Consolidated Report: Vol 1 The Mohaka-Waikare Confiscation and its Aftermath (research report commissioned by the Crown Forestry Rental Trust, WAI 201, J28, 1995), 59-89.

${ }^{61}$ On the Crown's purchasing activity see Richard Boast, The Mohaka-Waikare Confiscation Consolidated Report: Vol 2 The Mohaka-Waikere Blocks (research report commissioned by the Crown Forestry Rental Trust, WAI 201, J29, 1995), 132-42; on the state of the Tangoio community, see Boast, The Mohaka-Waikare Confiscation Consolidated Report: Vol 1, 206-18.

${ }^{62}$ Boast, The Mohaka-Waikare Confiscation Consolidated Report: Vol 2, 144-55.

${ }^{63}$ New Zealand Gazette, 14 March 1957, No. 22, 470.

${ }^{64}$ See for example P. Shadwell, for Secretary Internal Affairs to Secretary, Department of Maori Affairs, 8 June 1961, Archives New Zealand, file AAAC W3179 Box 14 46/29/24.

${ }^{65}$ Algal blooms were first recorded by G. A. Gunn, the local Acclimatisation Society Ranger, from 1959. They have persisted ever since. See Lake Tutira Technical Committee, Lake Tutira and its Catchment: Current Condition and Future Management (unpublished report to the Hawkes Bay Catchment Board, 1976), 2.

${ }^{66}$ The presence of Hydrilla was known since the early 1950s but officially confirmed by the Hawkes Bay Catchment Board in 1963. See P. J. Grant, Tutira Lake: A Comparison Between 1925 and 1963 (unpublished Hawkes Bay Catchment Board report, Archives New Zealand, file AAAW3207 Box 83 WIL 34/6/3 Part 1. 
${ }^{67}$ G. Walls, 1994. "The New Zealand Hydrilla Problem. A Review of the Issues and Management Options," Conservation Advisory Science Notes 71 (Department of Conservation, Wellington).

${ }^{68}$ The Department of Conservation had recommended use of grass carp as early as 1994.

${ }^{69}$ D. E. Hofstra, Flora and Fauna Survey for the Hydrilla Eradication Response, NIWA Client Report HAM2016-044 (May 2016); D. E. Hofstra, Hydrilla Monitoring Report 2017 Eradication Response, NIWA Client Report No: 2017383HN (November 2017).

${ }^{70}$ D. E. Hofstra and D. Rowe, Assessment of Environmental Effects for the Introduction of Grass Carp to Hydrilla Affected Lakes in Hawke's Bay, NIWA Client Report HAM2008-085 (June 2008).

${ }^{71}$ See "Lake Tutira and its Management: Current Condition and Future Management," report by the Tutira Technical Committee to the Hawkes Bay Catchment Board, Archives New Zealand, file AANS W3546 Box 41 WIL 34/6/3 Part 2, 2 and 8.

${ }^{72}$ Guthrie-Smith, Tutira, 204.

${ }^{73}$ Lake Tūtira's sediments are our primary record of these storms' frequency and intensity. See Page et al., "A High Resolution Record of Storm-Induced Erosion," 333-48.

${ }^{74}$ Guthrie-Smith, Tutira, 37.

${ }^{75}$ Eden and Page, "Palaeoclimatic Implications of a Storm Erosion Record," 43.

${ }^{76}$ M. J. Page, N. A. Trustrum, and J. R. Dymond, "Sediment Budget to Assess the Geomorphic Effect of a Cyclonic Storm, New Zealand," Geomorphology 9 (1994): 169-88; A. R. Orpin, L. Carter, M. J.

Page, U. A. Cochran, N. A. Trustram, B. Gomez, A. S. Palmer, D. C. Mildenhall, K. M. Rogers, H. L. Brackley and L. Northcote, "Holocene Sedimentary Record from Lake Tutira: A Template for Upland Watershed Erosion Proximal to the Waipaoa Sediment," Marine Geology 270 (2010): 11-29.

${ }^{77}$ At the Lakes Water Quality Symposium 2019 for the Rotorua / Te Arawa lakes, the North American limnologist Lars Anderson suggested understanding lakes is much harder than rocket science.

${ }^{78}$ Interview with Andy Hicks, 1 August 2019.

${ }^{79}$ Lake Tūtira is stratified for much of the year, and over 2011-2012 was mixed for only some 55 days a year. Dissolved oxygen is consumed very rapidly while the lake is stratified. Jonathan Abell, Chris G. McBride and David P. Hamilton, "Lake Tutira: Historic Water Quality, Monitoring

Recommendations and Management Options," Environmental Research Report 11 (Environmental Research Institute, University of Waikato, 2013), 14.

${ }^{80}$ Max M. Gibbs and Clive Howard-Williams, "Physical Processes for In-Lake Restoration:

Destratification and Mixing," in Lake Restoration Handbook: A New Zealand Perspective, ed. D.

Hamilton, K. Colllier, C. Howard-Williams (DOI: https://doi.org/10.1007/978-3-319-93043-5), 175.

${ }^{81}$ D. F. Burger, D. P. Hamilton, C. A. Pilditch, and M. M. Gibbs, "Benthic Nutrient Fluxes in a Eutrophic, Polymictic Lake, Hydrobiologia 584, no. 1 (2007): 24.

${ }^{82}$ Gibbs and Howard-Williams, "Physical Processes," 199-200. Also, interview with Max Gibbs, 25 June 2019.

${ }^{83}$ Interview with Max Gibbs, 5 April 2019.

${ }^{84}$ D. W. Schindler and J. R. Vallentyne, The Algal Bowl: Overfertilization of the World's Freshwaters and Estuaries (London: Taylor and Francis, 2008), 13.

${ }^{85}$ This was said to me by both Rex Graham, chair of the Hawkes Bay Regional Council, and Andy Hicks, the council's principal scientist. Interview with Rex Graham, 2 August 2019; interview with Andy Hicks, 1 August 2019.

${ }^{86}$ P. K. Simons, Chief Engineer Hawkes Bay Catchment Board and Regional Water Board, Lake Tutira Technical Committee, 3 November 1975, Archives New Zealand, file AANS W3546 Box 41 WIL 34/6/3 Part 2.

${ }^{87}$ Lake Tutira Technical Committee, Lake Tutira and its Catchment, 29.

${ }^{88}$ This was first proposed by DSIR scientist Rob McColl, leading scientist on the Lake Tutira Technical Committee, as early as 1975. He envisaged flood waters bypassing the lake but low flows being allowed in. Unfortunately, the reverse has occurred. See Rob McColl, "Lake Tutira: Phosphorus Balance and Management," in Archives New Zealand, file AANS W3546 Box 41 WIL 34/6/3 Part 2. 
${ }^{89}$ C. G. McBride and D. P. Hamilton, "Catchment and Lake Water Quality Modelling to Assess Management Options for Lake Tutira," client report prepared for Hawke's Bay Regional Council, Environmental Research Institute report 97 (Hamilton: The University of Waikato), 21-23.

${ }^{90}$ Laurel Tierney, "A Study and Manipulation of Lake Tutira October 1973-April 1977," MPI technical paper no: 2012/47, March 2009.

${ }^{91}$ Hawkes Bay Catchment Board and Regional Water Board, Lake Tutira Catchment Control Scheme: Five Year Review of Programme (unpublished report held by the Hawkes Bay Regional Council).

${ }^{92}$ Fisheries Research Division: Ministry of Agriculture \& Fisheries, Lake Tutira Project: Artificial Destratification (undated report held by the Hawkes Bay Regional Council). This concluded that the ministry could no longer justify the finance required to continue destratification.

${ }^{93}$ Fenton Wilson, Chairman Hawkes Bay Regional Council, "Foreword," in A Short History of Tutira Country Park, Garth Eyles, (Napier: Hawkes Bay Regional Council, 2014).

${ }^{94}$ See the terms of the Maungaharuru-Tangitū Deed of Settlement, available at https://www.govt.nz/assets/Documents/OTS/Maungaharuru-Tangitu-Hapu/Maungaharuru-TangituDeed-of-Settlement-25-May-2013.pdf. The northern portion of the bed of Lake Tütira is held by the Māori owners of Tūtira B 19 Block.

${ }^{95}$ The Maungaharuru-Tangitū Trust and Hawkes Bay Regional Council collaborated on the 2016 Tūtira Mai Ngā iwi project, which sought to improve the mauri and water quality of Lake Tūtira, through wānanga, pest plant removal, planting, fencing, science reporting, landowner and community engagement. Tūtira Mai Ngā Iwi was jointly funded through the Tangoio Soil Conservation Fund and Te Mana o Te Wai Fund. In 2018 they together secured funds for Project Te Waiū o Tūtira (the milk of Tūtira) from the Freshwater Improvement Fund. This will provide a community-driven integrated catchment management plan for Tūtira, a cultural monitoring programme, ongoing riparian planting, sediment traps, and farm environmental management plans, subsidy schemes and land management support for local landowners.

${ }^{96}$ Interviews with Andy Hicks and Thomas Petrie, 1 August 2019.

${ }^{97}$ Aeration via an air curtain, designed to destratify the lake, was adopted following the recommendations of Max Gibbs. It has been trialled on Lake Waikopiro, a small lake immediately adjacent to Lake Tūtira. Interview with Andy Hicks, 1 August 2019.

${ }^{98}$ Interview with Tania Hopmans, 31 July 2019.

${ }^{99}$ Interview with Andy Hicks, 1 August 2019. See also Bridget Freeman-Rock, "Saving Lake Tutira," The Buzz, 1 October 2017, https://www.baybuzz.co.nz/2017/10/01/saving-lake-tutira/.

${ }^{100}$ McBride and Hamilton, "Catchment and Lake Water Quality Modelling," 39-40. As much as 84 percent $(1,752 \mathrm{ha})$ of the Papakiri Stream catchment is either in dry stock or dairy production.

${ }^{101}$ Interview with Andy Hicks, 1 August 2019.

${ }^{102}$ McBride and Hamilton, "Catchment and Lake Water Quality Modelling," 46.

${ }^{103}$ For discussion of the "colonial keyword" improvement, see Tony Ballantyne, "Culture and Colonization: Revisiting the Place of Writing in Colonial New Zealand," Journal of New Zealand Studies 9 (2010): 14; James Beattie and John Stenhouse, "Empire, Environment and Religion: God and the Natural World in Nineteenth-Century New Zealand," Environment and History 13, no. 4 (2007): 413-46; in the wider imperial context, see Richard Drayton, Nature's Government: Science, Imperialism, and the "Improvement of the World" (New Haven: Yale University Press, 2000). ${ }^{104}$ Interview with Charles Rudd, 17 April 2019. Also, on some accounts, Te Moana o Punahau, or Te Takere Tangata o Punahau. See Waitangi Tribunal, Horowhenua: The Muaūpoko Priority Report (Wellington, Waitangi Tribunal, 2017), 251. For the nature and extent of groundwater influence see Max Gibb, "Lake Horowhenua Review: Assessment of Opportunities to Address Water Quality Issues in Lake Horowhenua" (NIWA client report for Horizons Regional Council, National Institute of Water and Atmospheric Research, June 2011), 20-21.

${ }^{105}$ Anne-Gaelle E. Ausseil, John R. Dymond, and James D. Shepherd, "Rapid Mapping and Prioritisation of Wetland Sites in the Manawatu-Wanganui Region, New Zealand," Environmental Management 39, no. 3 (2007): 39; Geoff Park, Nga Uruora: The Groves of Life (Wellington: Victoria University Press, 1995), 207-10. 
${ }^{106}$ Anthony Dreaver, Horowhenua County and its People: A Centennial History (Palmerston North: Dunmore [for Horowhenua County Council], 1984), 23.

${ }^{107}$ George Leslie Adkin, Horowhenua: Its Maori Place-Names and their Topographical and Historical Background (Wellington: Polynesian Society Memoir 26, 1948), 4.

${ }^{108}$ Anthony Dreaver, Levin: The Making of a Town (Levin: Horowhenua District Council, 2006), 51.

${ }^{109}$ Levin was only settled in the 1890s, and as early as 1897 a public meeting in Levin petitioned the government "lose no time" acquiring Horowhenua and Waiwiri (Lake Papaitonga): "Local and General," Evening Post, 31 December 1897, 4, cited in Paul Hamer, “'A Tangled Skein': Lake Horowhenua, Muaūpoko, and the Crown, 1898-2000" (report commissioned by the Waitangi Tribunal for the Porirua ki Manawatū inquiry [Document A150, Wai 2200], June 2015), 26. Levin's settlers had Premier Seddon visit in 1903 and rowed him around on the lake, securing a promise from him to acquire the lake for a reserve or national park; the settlers' member William (Willy) Field followed this up in Parliament, repeatedly inquiring when would "the promised nationalisation" occur?

${ }^{110}$ Central government has repeatedly tried to disentangle itself from the arrangements Parliament has legislated. For helpful discussion see Hamer, “A Tangled Skein,” 279-90, 378-83.

${ }^{111}$ The 1905 agreement and the legislation that followed were the key political events that have shaped control of the lake. Unfortunately, there are no contemporary records of the meeting at which the agreement was apparently reached. We know only that Premier Seddon and Native Minister Carroll attended, together with Wiki Keepa (who officials thought led the Muauppoko party), Wirihana Hunia, and a young man named Wī Reihana, with Field representing the Levin settlers. No one has been able to find a copy of the agreement either; its purported terms are set out in an undated list on a file of miscellaneous papers relating to the Horowhenua XI block. See "Horowhenua Lake Agreement," Archives New Zealand, file ACIH 16082 MA75 4/24. For discussion, see Hamer, "A Tangled Skein," 34-38.

112 These were the complaints of the Muaūpoko deputation that met the Minister of Internal Affairs in Wellington in October 1830. They were corroborated, with respect to eels, by a government inspection: "Notes of a Meeting Between Muaupoko Representatives and the Minister of Internal Affairs, 21 October 1930," Archives New Zealand, file ACGO 8333 IA1 1380 19/10/51, cited in D. A. Armstrong, "Lake Horowhenua and the Hokio Stream 1905-c1990" (a report lodged on the Waitangi Tribunal's record for the Porirua ki Manawatū inquiry [Document A162, Wai 2200], 2017), 45; A. E. Hefford, Chief Inspector of Fisheries, to Secretary, Marine Department, 17 February 1931, Archives New Zealand, file ADOE 16612 M1 76 1/7/102.

${ }^{113}$ Commissioner of Crown Lands to Director-General of Lands, 26 January 1954, Archives New Zealand, file AANS W5491 6095 Box 158 1/220 part 4; "Stabilisation of Level of Lake Discussed by Board," Chronicle, 21 June 1957, clipping in Archives New Zealand, file AANS W5491 6095 Box $1581 / 220$ part 5. The agreement struck in 1956 was enshrined in legislation via section 18 of the Reserves and Other Lands Disposal Act 1956.

${ }^{114}$ Gibbs, "Lake Horowhenua Review," 59-60.

${ }^{115}$ Max Gibbs, "Eutrophication by Act of Parliament: The Unique Story of Lake Horowhenua," Presentation to NIWA seminar series, Hamilton, 15 November 2011.

${ }^{116}$ All secondary sources, including the recent Waitangi Tribunal research and reports, date the initial operation of Levin's new sewage system to 1952. However, this was when funding was secured. Newspaper reports and government correspondence are clear the plant and the reticulation necessary for the scheme to work was actually constructed in phases over 1953 and 1954. See "Councillor Sick of Sewerage Scheme Recriminations," Chronicle, 21 January 1954; "Debate on Sewerage Continues, Dominion, 3 February 1954. Clippings in Archives New Zealand, file AAFB W3563 16/32/175. See also Medical officer of Health to Director-General of Health, 12 February 1963, Archives New Zealand, file AAFB W3563 16/32/175; Acting Medical Officer of Health to Director-General of Health, 18 November 1964, Archives New Zealand, file AAFB W3563 632 Box 16 32/175. Also, "Sewerage System in Dispute as Early as 1908," Chronicle 75th Jubilee issue, March 1981, 111. ${ }^{117}$ Levin Abattoirs-Disposal of Meat Wastes," Archives New Zealand, file AAFB 632 W3563 16 32/175 37322; Medical Officer of Health to Director-General of Health, 8 September 1964, Archives New Zealand, file AAFB W3563 632 Box 16 32/175 37322. 
${ }^{118}$ When students of Horowhenua College studied the lake in 1975 they observed pigs and other stock in the lake, pig waste being discharged directly into the lake, and dairy effluent overflowing into the lake. See C. A. Mcllroy, Chairman Horowhenua Domain Board to Commissioner for the Environment, 5 May 1975, Archives New Zealand, file AAUM W4043 Box 221 NRS 3/6/Z Part 1. These observations were corroborated by officials: see "Pollution: Lake Horowhenua," Nature Conservation Council Meeting 17 September 1975, Archives New Zealand, file AAZU W3619 Box $1331 / 11 / 71$. This notes that "stock trespass to the water-line is not uncommon including pigs on a pig farm."

${ }^{119}$ Gibbs and Quinn, "Restoration Plan for Lake Horowhenua," 7-8. Data on the lake's trophic state is publicly available at: https://www.lawa.org.nz/explore-data/manawat\%C5\%AB-whanganuiregion/lakes/lake-horowhenua/.

${ }^{120}$ Karl du Fresne, "Lake of Shame: New Report Vindicates the Man Fighting to Save Lake Horowhenua," New Zealand Listener, 29 August 2017. Available at https://www.noted.co.nz/planet/planet-planet/lake-of-shame-new-report-vindicates-the-man-fightingto-save-lake-horowhenua.

121 "Levin Borough Drainage," memorandum for the solicitor-general, Wellington, 11 June 1942, in supporting papers to D. A. Armstrong, Lake Horowhenua and the Hokio Stream, 1905-c.1990 (report filed in the Waitangi Tribunal's Porirua ki Manawatū inquiry [Document A162f, Wai 2200], June 2015), 3449.

${ }^{122}$ Under Secretary, Native Department, to Director-General of Health, 15 December 1944, Archives Central file HDC 00010: 14: 26/3, cited in Hamer, "A Tangled Skein," 199-200.

${ }^{123}$ Hamer, "A Tangled Skein," 209 fn 920.

${ }^{124}$ Vickerman and Lancaster, consulting engineers, to Town Clerk Levin, 10 June 1948, 9 December 1948, and 3 February 1949, Archives New Zealand, file ABDZ 16163 H1 1580 32/175.

${ }^{125}$ Medical Officer of Health to Director-General of Health, 9 May 1949, Archives New Zealand, file ABDZ 16163 H1 1580 32/175.

${ }^{126}$ Appendix to the Journals of the House of Representatives, 1896, G-2, 296-97.

${ }^{127}$ Dreaver, Levin, 243; Submission of L. B. Roberts to Water Resources Council hearing on preliminary reclassification of Lake Horowhenua to class CX, Levin, 29 November 1979, Archives New Zealand, file AAYY W4182 18152 Box 63 32/3/3 part 1.

${ }^{128}$ For discussion of why it took so long to stop using the lake to dispose of sewage effluent, see Hamer, "A Tangled Skein," 170-71.

${ }^{129}$ For the lake's nutrient budget see Lake Horowhenua Technical Committee, "Lake Horowhenua: Current Condition, Nutrient Budget and Future Management" (March 1978). It was calculated sewage effluent contributed 86 percent of the phosphorus and 27 percent of the nitrogen entering the lake. Cowshed effluent contributed significantly also. For Hughes' views on recovery, see H. R. Hughes, for Director-General, DSIR, to Chair of the Horowhenua Lake Domain Board, 11 November 1975, Archives New Zealand, file AAYY W4182 18152 Box 63 32/3/3 part 1.

${ }^{130}$ Gibbs, "Lake Horowhenua Review"; Gibbs and Quinn, "Restoration Plan for Lake Horowhenua," 10-11; interview with Max Gibbs, 25 June 2019.

${ }^{131}$ Interview with Max Gibbs, 25 June 2019.

132 This is higher than reported elsewhere, for example, G. S. Francis , L. A. Trimmer, C. S. Tregurtha, P. H. Williams \& R. C. Butler, "Winter Nitrate Leaching Losses from Three Land Uses in the Pukekohe Area of New Zealand," New Zealand Journal of Agricultural Research, 46 (2003):

215-24. They found leaching under potatoes was much higher than other land uses but was at $114 \mathrm{~kg}$ N/ha. However, I rely on "Section 42A Report of Dr. Brent Euan Clothier on behalf of Horizons Regional Council," 36-38. Available at https://www.horizons.govt.nz/HRC/media/Media/One\%20Plan\%20Documents/Dr-Brent-EuanClothier.pdf?ext=.pdf. This report states that data was obtained "from a large commercial vegetable enterprise near Levin," and this data was used to validate a model for predicting leaching. The model predicted "some $431 \mathrm{~kg} / \mathrm{ha}$ of nitrate-N was leached during the two-year observation period." The model had good correspondence with the observed data samples. 
${ }^{133}$ NO3-N concentrations had a mean of $12,960 \mathrm{mg} / \mathrm{m} 3$ between 2000 and 2010 . Gibbs Lake

Horowhenua Review, 34.

${ }^{134}$ Interview and subsequent emails with Max Gibbs, 5 April and 15 April 2019.

135 The latest such accord is He Hikoio Rerenga Tahi, signed in August 2013, the five parties to which are the Lake Horowhenua Trust, the Horowhenua Lake Domain Board, Horowhenua District Council, Horizons Regional Council, and the Department of Conservation.

${ }^{136}$ Interview with Michael Feyen, 13 May 2019.

${ }^{137}$ Gibbs, Lake Horowhenua Review, 10.

${ }^{138}$ The original OnePlan can be found on Horizon's website:

https://www.horizons.govt.nz/publications-feedback/one-plan-documents/\%e2\%80\%a2proposed-oneplan-as-marked-up-with-appeals-(dece

${ }^{139}$ Bruce Wills, 'Bruce Wills Still Thinks the Horizons One Plan could create 'Farmageddon' and Calls for a More Considered Balance. Your View?" Interest, 9 November 2012,

https://www.interest.co.nz/rural-news/61959/bruce-wills-still-thinks-horizons-one-plan-could-createfarmergeddon-and-calls-more Accessed 15 April 2019.

${ }^{140}$ Andrew Day \& Ors v Manawatu-Wanganui Regional Council [2012] NZ Environment Court 182, para 5-11.

${ }^{141}$ Andrew Day \& Ors v Manawatu-Wanganui Regional Council [2012] NZ Environment Court 182, para 5-60.

${ }_{142}$ Wellington Fish and Game v Manawatu-Wanganui Regional Council [2017] NZ Environment Court 37, para 16.

${ }^{143}$ Interview with Nic Peet, 1 May 2019.

${ }^{144}$ The Lake Horowhenua Report Card, issued in December 2017 as part of the Lake Horowhenua Accord of 2013, states Total Phosphorus (TP) levels have an annual mean of $250 \mathrm{mg} / \mathrm{m} 3$. The National Bottom Line is $50 \mathrm{mg} / \mathrm{m} 3$. Total Nitorgen (TN) has a mean of $1910 \mathrm{mg} / \mathrm{m} 3$, whereas the National Botton Line is $800 \mathrm{mg} / \mathrm{m} 3$. Avaliable at http://www.horizons.govt.nz/HRC/media/Media/Water/Lake-Horowhenua-Report122017.pdf?ext=.pdf.

${ }^{145}$ Interview with Nic Peet, 1 May 2019.

146 Jono Galuszka, "One Plan to be Changed Amid Fears of Farm Closures and \$15 Cabbages," Stuff, 9 August 2017. Available at https://www.stuff.co.nz/business/farming/agribusiness/95600485/oneplan-to-be-changed-amid-fears-of-farm-closures-and-15-cabbages.

${ }^{147}$ His Honour J. D. Ormond to the Hon. the Colonial Secretary, 6 October 1869, in Appendix to the Journals of the House of Representatives 1870, Session 1, A8, 20.

${ }^{148}$ Deborah H. Maxwell, "A Rainfall-Runoff Model for the Highly Regulated Lake Taupo Catchment, Using a Constrained Ensemble Kalman Filter to Improve the Accuracy and Reliability of Model Output," (PhD diss., Victoria University of Wellington, 2013), 12-13. Part of the current catchment derives from water diverted to the lake by the Tongariro Power Diversion.

${ }^{149}$ R. Gerrard Ward, "Land Development in the Taupo County," New Zealand Geographer 12 (1956): 115-32; Wildlands Consultants Limited, History of Land Development in the Lake Taupo Catchment, Waikato Regional Council Technical Report 2013/26.

${ }^{150}$ Taupo County Council, Lake Taupo (Taupo-nui-a-Tia): An Investment for the Nation (1965).

${ }^{151}$ D. Kennedy, Conservator of Forests, Rotorua to Director-General, Wellington, 26 March 1965, Archives New Zealand, file AAAC W5224 6015 Box 207 103/462 Part 1.

${ }^{152}$ This theme suffuses the Taupo County Council's proposals. See also, as an example, Bernard Ferguson, Governor General, to Minister for Internal Affairs, 31 December 1965, Archives New Zealand file AAACW5224 6015 Box 207 103/462 Part 2.

${ }^{153}$ See "Report of the Officials Committee on Lake Taupo Reserves February 1966," Archives New Zealand, file AAAC W5224 6015 Box 207 103/462 Part 2. This comprised 22,000 acres of Mãori land, 13,470 acres of Crown land and reserves and state forest, and just 2,530 acres of private freehold land.

${ }^{154}$ There was naturally a range of views within the iwi as to whether, and in what circumstances, parts of the tribal estate might be set aside, but the government's poor process was universally condemned, 
and the iwi were quick to tell them so. See for example R. Tripe (on behalf Tuwharetoa Maori Trust Board) to Minister of Internal Affairs, 25 September 1964; Pei Jones to Minister of Internal Affairs, 21 October 1964; J. A. Asher to Minister for Internal Affairs, 9 December 1964, Archives New Zealand, file AAACW5224 6015 Box 207 103/462 Part 2; also Bernard Ferguson, Governor General, to Minister for Internal Affairs, 31 December 1965, Archives New Zealand file AAACW5224 6015 Box 207 103/462 Part 2.

${ }^{155}$ It is unclear how much of this land was ever actually acquired from Ngāti Tūwharetoa. However, the reserve designations put in place by the Taupo and Taumarunui County Councils certainly hampered any development of their land until removed, in some cases not until the late 1980s. See Waitangi Tribunal, He Maunga Rongo Report (Wellington: Legislation Direct, 2008), 1428; P. McBurney, Scenery Preservation and Public Works Takings (Taupo-Rotorua) c. 1880s-1980, report commissioned by the Crown Forestry Rental Trust, 2004 (Wai 1200, A082(b)), 322-24.

${ }^{156}$ Taupo Basin Co-ordinating Committee, Minutes of the Inaugural meeting held at Turangi on Monday 16 December 1968, Archives New Zealand, file AAAC W5224 6015 Box 208 103/462/7 Part 1.

${ }^{157}$ Secretary, Taupo Basin Coordinating Committee, to Chairman, Officials Committee for the Environment, 24 April 1973, Archives New Zealand, file AAUM W4043 Box 220 NRS 3/61 Part 1.

${ }^{158}$ Successive governments were very proud of efforts to protect Taupō, and in 1972 Duncan MacIntyre, Minister for the Environment, presented them as a case study to the United Nations Conference on the Environment, in Stockholm. This presentation was published as The Taupo Basin: A New Zealand Study in Environmental Management (Wellington: Environmental Council of New Zealand, 1971). This then helped secure $\$ 1.9$ million of central government funding for the Waikato Valley Authority's efforts to plant and fence the streams running into Taupō. See Waikato Valley Authority, Lake Taupo Catchment Control Scheme: Final Report (Hamilton: Waikato Valley Authority, 1973). This also sets out the extent to which land development around Taupō was almost entirely government directed. A total of 46,952 hectares was then in pasture in the Taupō Basin, of which most was either still Crown-owned (22,055 ha), or freehold but derived from Crown-developed land (8,498 ha). Much of the Māori land in pasture (16,339 ha) was administered by the Department of Maori Affairs. See "An Economic Evaluation of the Lake Taupo Catchment Control Scheme," Appendix VII to Waikato Valley Authority, Lake Taupo Catchment Control Scheme.

159 "Taupo Chosen As Centre For Lake Research," New Zealand Herald, 21 April 1973. Clipping in Archives New Zealand, file AAUM W4043 Box 220 NRS 3/61 Part 1.

${ }^{160}$ Agriculture New Zealand, Woodward Clyde Limited, Geoff Butcher \& Associates, Ministry of Agriculture and Fisheries, "Impacts of Dairy Conversions in the Taupo District," jointly commissioned by MAF Policy and Environment Waikato, MAF Policy Technical Paper 97/9. See map between pages 27 and 28 .

${ }^{161}$ B. Vant and B. Huser, "Effects of Intensifying Catchment Land-Use on the Water Quality of Lake Taupo," Proceedings of the New Zealand Society of Animal Production 60 (2000): 261-64.

${ }^{162}$ Increases in nutrients have a linear relationship with increases in algae. However, additions of algae have a hyperbolic relationship with reductions of water clarity. See Vant and Huser, "Effects of Intensifying Catchment Land-Use," 263.

${ }^{163}$ Interview with Bill Vant, 25 June 2019.

${ }^{164}$ See Federated Farmers of New Zealand Incorporated $v$ Bay of Plenty Regional Council [2019] NZ Environment Court 136.

${ }^{165}$ The Taupō scheme has attracted significant commentary from policy makers. See, for example: The Lake Taupo Nitrogen Market in New Zealand: Lessons in Environmental Policy Reform, OECD Environmental Policy Paper No. 4, September 2015. Madeline Duhon, Hugh McDonald and Suzi Kerr, "Nitrogen Trading in Lake Taupo: An Analysis and Evaluation of an Innovative Water Management Policy," Motu Working Paper 15-07, Motu Economic and Public Policy Research, June 2015.

${ }^{166}$ The agreed goal is to reduce manageable nitrogen leaching into the lake by 20 percent (as calculated at 2001, the year cyanobacteria were first noticed in the lake). See B. Vant, "Recent Changes in Water Quality of Lake Taupo and its Inflowing Streams," New Zealand Journal of 
Forestry 58 (2013): 27-30. It was intended this would be achieved by foresting pastoral land. The Lake Taupo Protection Trust was established as an independent body, to fulfil this task (which it has successfully done). See Cabinet Paper, "Advancing Negotiations to Protect Lake Taupo," December 2003, Appendix F to Sue Yerex, "Protecting Lake Taupo: The Strategy and the Lessons," prepared for Kellogg Rural Leadership Programme 2008, Available at:

https://www.protectinglaketaupo.nz/assets/Protecting-Lake-Taupo/The-Trust/Key-Documents/2009Lake-Taupo-Project-Review.pdf.

${ }^{167}$ Interview with Mike and Sharon Barton, 28 August 2019.

${ }^{168}$ Interview with Mike and Sharon Barton, 28 August 2019.

${ }^{169}$ See https://www.taupobeef.co.nz/.

${ }^{170}$ Interview with Mike and Sharon Barton, 28 August 2019.

${ }^{171}$ Sandra Barns and Justine Young, "Cap-and-Trade of Diffuse Emissions of Nitrogen in Lake Taupo Catchment. Reviewing the Policy Decisions and the Market," Waikato Regional Council Technical Report 2013/34, 3-4.

${ }^{172}$ Barns and Young, "Cap-and Trade," 21 fn18. As at 2007 there were 100 blocks of 20-100

hectares, and 92-100 blocks greater than 20 hectares. A further 5 percent of the catchment was held in around 1000 blocks of under 20 hectares.

${ }^{173}$ Justine Young and Geoff Kaine, "Application of the Policy Choice Framework to Lake Taupo Catchment Environment," Waikato Technical Report 2010/20, December 2009. Young and Kaine identify six dairy farms wholly or partly within the catchment.

${ }^{174}$ The role of central government in catchment development was a critical point in negotiations between central and local government, as is evident in the Cabinet papers. These are attached (with minor redactions) as Appendices E, F and I to Sue Yerex, "Protecting Lake Taupo: The Strategy and the Lessons," prepared for Kellogg Rural Leadership Programme 2008, Available at:

https://www.protectinglaketaupo.nz/assets/Protecting-Lake-Taupo/The-Trust/Key-Documents/2009Lake-Taupo-Project-Review.pdf. See also Barns and Young, "Cap-and-Trade."

${ }^{175}$ This is the case with the Rotorua lakes, for example, where efforts to replicate the Taupo model are facing difficulties due to much higher land values. There, the efforts to incentivise farmers to change land use by buying nitrogen at the same price as in Taupo ( $\$ 400$ per tonne) have had limited success. Interview with Don Atkinson, 26 June 2019.

${ }^{176}$ See the TEDx talk by Mike and Sharon Barton, available at https://www.youtube.com/watch?v=Sx9JtIuj6_o.

${ }_{177}$ At the time of writing, the plan change needed to enshrine the Lake Rotorua scheme had passed its initial hurdle in the Environment Court, confirming the allocation model proposed (a modified form of grandparenting) but faced a further set of court challenges before final confirmation. See Federated Farmers of New Zealand Incorporated $v$ Bay of Plenty Regional Council [2019] NZ Environment Court 136.

${ }^{178}$ For Taupō, see Uwe Morgenstern, "Lake Taupo Catchment Groundwater Age Distribution and Implications for Future Land-Use Impacts," Environment Waikato Technical Report 2007/49. For Rotorua, see U. Morgenstern, C. J. Daughney, G. Leonard, D. Gordon, F. M. Donath, and R. Reeves, "Using Groundwater Age and Hydrochemistry to Understand Sources and Dynamics of Nutrient Contamination Through the Catchment into Lake Rotorua, New Zealand," Hydrology and Earth System Sciences 19 (2015): 803-22. Groundwaters in western and northern Taupō are especially old, with mean residence times of between 20 and 180 years. The "load to come" has become a colloquial term of art in the area.

${ }^{179}$ This is a reference to government policy released on 8 October 2018, promising a noticeable improvement in water quality within five years. See David Parker, "Taking Action to Improve Water Quality," available at https://www.beehive.govt.nz/release/taking-action-improve-water-quality.

${ }^{180}$ Interview with David Hamilton, 26 July 2019.

${ }^{181}$ Henry Thoreau, Walden or, Life in the Woods (London: David Campbell Publishers, 1992), 166.

182 Thoreau, Walden.

${ }^{183}$ Interview with Mike Barton, 28 August 2019. 